\title{
Building Visual Intertextuality and Territorial Identities for the Romanian Danubian Settlements during Socialism
}

\author{
Oana-Ramona ILOVAN 1, 2, Florentina-Cristina MERCIU*3 \\ * Corresponding author \\ 1 Babeș-Bolyai University, Faculty of Geography, Department of Regional Geography and Territorial Planning, Territorial Identities \\ and Development Research Centre, Cluj-Napoca, ROMANIA \\ 2 Humboldt-Universität zu Berlin, Department of Geography, Berlin, GERMANY \\ 3 University of Bucharest, Faculty of Geography, Interdisciplinary Center of Advanced Research on Territorial Dynamics, Bucharest, \\ ROMANIA \\ $\triangle$ oana.ilovan@ubbcluj.ro (D) https://orcid.org/oooo-00o3-2075-1808 \\ $\triangle$ cristina.merciu@geo.unibuc.ro (iD https://orcid.org/oooo-ooo3-2993-5136 \\ DOI: 10.24193/JSSPSI.2021.7.03 \\ https://doi.org/10.24193/JSSPSI.2021.7.03
}

K e y w o r d s: Danubian landscape, discourse analysis, critical visual methodology, school textbooks, picture postcards, communist narrative

\begin{abstract}
A B S T R A C T
The politics of symbolic representation is uncovered by our examining the represented cultural landscape. In this process, semiotics and discourse analysis were the methods complementing each other and enabling us to underline how Romanians' understanding of power relations, of past and present events and ultimately of reality was shaped by signs, symbols, and stories in official visual materials. This research aims to discuss the geography of Romania's southern border during the socialist period (1948-1989). This geography is made of the Danube and of the Danubian settlements as represented in images within Geography of Romania school textbooks and picture postcards. Thus, the aim of our article is to decode the visual construction of territorial identity of the Danubian settlements in Romania. To reach this aim, we considered the following research questions: Is the Danube the main subject in these representations or a secondary one? How is the Danube represented? What are the key-themes of its representation? How is the past of the settlements on the Danube integrated into the visual discourse during the socialist period? What was the role played by the Danube in the history of these settlements according to these representations (i.e. textbooks and picture postcards)? Results show that the Danube is a liminal space, changing functions depending on historical, political, economic, and social circumstances. The Danube is represented as landscape, defined through its economic (i.e. transport, commerce) or historical functions (i.e. border to the south or communication route with the west). Due to its representations, also the other elements seem truthful and "natural". The presence of people and activities in the displayed places inform and educate visitors and inhabitants how to use space (contemplative, for entertainment, for relaxation, to learn, etc.). We provide an informed understanding of Romania through visual imagery: representations are singling out its uniqueness and achievements, fitting into the metanarrative of socialist propaganda.
\end{abstract}

\section{INTRODUCTION}

"Beautiful and rich is our homeland. Page by page, the geography book has shown us how beautiful and rich is our country. Lying in that part of Europe where coldness and warmth shake their hands, where the mountains, the hills, and the fields mix harmoniously into a land of rare beauty, crossed by clear and cold waters, tight-belted in the south by the silver Danube and bathed in the east by the foaming 
waters of the Black Sea - Romania is our homeland, precious inheritance from our ancestors" (our transl., Iancu, Motrescu and Negulescu, 1985, pp. 121-122).

The quotation above encloses in a nutshell the socialist metanarrative about Romania: a beautiful and rich inheritance of the Romanian people, who should cherish it, as well as its history. We argue that, during socialist Romania (1948-1989), the official state policies and discourses guided the reordering of space and of Romanians' visualizations of the national territory at the southern border of Romania, in the form of the Danube, with Yugoslavia (235.5 km) and with Bulgaria $(469.5 \mathrm{~km})$. This reordering and the production of a new visuality (i.e. way of seeing) rendered urban development as a political and historical product.

In this article, we explore the medium of photography as a specific kind of intercultural text used in two sources distributed in socialist Romania: Geography of Romania school textbooks and picture postcards. We argue that social, economic, and political processes shape the selected visual imagery. Cultural production is structured by all these societal processes and visual materials are cultural products of a documentary nature. In addition to visual imagery, visualities are specific to each society: "ways of seeing are historically, geographically, culturally and socially specific" (Rose, 2014, p. 17; cf. also Banini and Ilovan, 2021a, 2021b).

However, when selecting and interpreting images, we were concerned with avoiding to search for photographs that only confirmed what we supposed about them: being representations of territorial identity based on past heritage and contemporary development. We knew from our previous studies on representations of socialist Romania in picture postcards that this was the case (cf. Ilovan and Maroşi, 2018; Ilovan, 2020d; Merciu, Cercleux and Merciu, 2021). Rather, in this research, we wanted to see how narratives were created about the territorial identities of the urban settlements on the banks of the Danube.

We have chosen the Danubian case study because it is a region of Romania whose evolution was profoundly marked due to its status as a border area and due to the Danube-related development, thus strongly connecting historical and geographical factors. Territorial identities narratives were interpreted for the eighteen Danubian settlements of Romania selected for this study. In such narratives, we aimed to establish what was the relationship between the various images, answering to the following: What are the key themes for the territorial identity of border Danubian settlements as represented in geography of Romania school textbooks and in picture postcards? How was national space produced by visual representations of the period? Which are the key visual themes in images of development? What is the knowledge required to construct and read "correctly" these visual materials?
What are the icons in the analysed visual imagery, which of the represented objects repeat, what is the purpose of placing those images in a certain relation?

After a brief review of the scientific literature on the subject, this contribution goes on to examine the building of territorial identities for the Romanian Danubian settlements during socialism by means of visual intertextuality.

\section{STATE OF THE ART}

Beginning with the 1970s, culture became crucial in understanding social life (processes, identities, changes) and, in Geography, this focus shift was described as the "cultural turn" (Banini, 2019, pp. 14-15). This visual rendering of the world is a representation process, whose products are never neutral or innocent. Visual representations interpret the world, they "read" it in a certain way and then they advertise it for other eyes (Ilovan et al., 2019). This means that an ideology-guided pedagogy of space through visual representations can influence viewers to interpret the world and society in broadly similar ways (Hall, 1997, p. 2). However, this does not exclude that various groups may differ in the ways they make sense of the world. Representations structure the way we create meanings and behave; therefore, it is significant for understanding present opinions, attitudes, and behaviours to analyse and understand past representations. Especially as representations are passed down, more or less altered, to the next generations.

Either explicit or implicit, the made meanings or representations are very influential and impact our lives, especially in the visual form, because the visual is central to our direct perception of the world, through the senses, and it has also become so due to the increasing number of produced visual materials that contribute to the cultural construction of our social life: "modernity is ocularcentric" (Rose, 2014, p. 4).

In this context, our theoretical approach and methodology are inspired by two key concepts: discourse and intertextuality. According to Rose, discourse "refers to groups of statements that structure the way a thing is thought, and the way we act based on that thinking. In other words, discourse is a particular knowledge about the world which shapes how the world is understood and how things are done in it" (2014, p. 190). This definition enabled our argumentation that the official discourse in visual imagery constructed accounts of socialist Romania as a successful political, economic, social, and cultural societal project. Considering this framework, the concept of intertextuality underlines that texts are placed in relation to other texts and that discourses are the result of their interaction: "intertextuality refers to the way that the meanings of any one discursive image or text 
depend not only on that one text or image, but also on the meanings carried by other images and texts" (Rose, 2014, p. 191; cf. also Barthes, 1977 and Kristeva, 1980).

Previous research showed that political regimes shaped urban spaces (Czepczyński, 2008; Diener and Hagen, 2013; Drummond and Young, 2020; Lefebvre, 1991; Light and Young, 2010; Zukin, 1993), imposing a new spatial organization and new symbols. Like the constructed urban cultural landscapes, their representations are "configurations of symbols and signs" (Cosgrove and Jackson, 1987, p. 96). During socialism, which was defined "as a system of governance and as a source for ideas about how to 'perfect' the city" (Drummond and Young, 2020, p. 6), planning all aspects of life and the territory were key state activities (cf. Cucu, 2019; Zahariade, 2011).

Socialist political, economic, and social circumstances are reflected into the territorial identities of areas at the local, regional, and national level. By territorial identity, we understand the distinguishing physical, cultural, and historical features that make an area different from another one (Ilovan, 2020b, p. 17). Within this context, the representation is defined as "a symbol or image, or as the process of rendering something (an object, event, idea, or perception) intelligible and identifiable" (Dubow, 2009, p. 645). Another approach is under the sign of social construction, and representation is defined as a discursive practice (Dubow, 2009, p. 646). Reflecting the territorial identity features of an area, representations are mental images of reality, which were transformed or constructed through cognitive processes (Ilovan et al., 2019).

Images are visual representations that are produced and circulated through various media. School textbooks and picture postcards are the two media providing the research material of this article. In recent years, research on the hidden agendas of educational discourses in school textbooks has become richer (cf. Bagoly-Simó, 2013, for a longitudinal analysis of research on geography textbooks). Many articles focus on analysing especially Geography and History textbooks, discussing the representations they circulate, such as representations of the Other in Geography textbooks (Hajdú and Paasi, 1995), changing images of countries (Paasi, 1999), national territories in postSoviet textbooks (Silova, Yaqub and Palandjian, 2014), the relationship between nation, state, school, and textbook (Williams, 2014), the diverse roles of textbooks (Venezky, 1992), and the politics of the textbook (Apple and Christian-Smith, 1991).

It is a fact that Geography builds canons (Mayhew, 2015), but during totalitarian political regimes, also the scientific canon of Geography was shaped (Caramelea, 2015; Dulamă and Ilovan, 2015, 2017; Dulamă et al., 2019). The topics are those preferred by the governing ideology and by the political hegemonic discourse (Kučerová, Kučera and Novotná, 2018). History and social studies textbooks have been researched in their connection to national identity and cultural representations (Mârza, 2015), while "the discursive construction of geography and how it relates to national identity" was not a primary subject (Silova, Yaqub and Palandjian, 2014, p. 109). However, several studies exist so far emphasizing the necessity of realising a critical discourse analysis of school textbooks (Hajdú and Paasi, 1995; Paasi, 1999). A close connection between power and the production of geographical knowledge was underlined in previous research (Hajdú and Paasi, 1995; Ilovan, 2020c; Paasi, 1999; Silova, Yaqub and Palandjian, 2014). Features of land and people were represented in textbooks, as the truth or reality of the political regime.

Geography of Romania textbooks were scrutinised for their ideological discourse during the 1864-1945 period (Caramelea, 2015), the first decades of the $2 \mathrm{O}^{\text {th }}$ century (Ilovan, 2020c), and the socialist one (Ilovan, Bagoly-Simó and Herbstritt, 2018). These studies are shaped by the same or similar research aims as in other recent studies at the international level (cf. Kučerová, Kučera and Novotná, 2018).

Besides research on Geography of Romania textbooks, at the national level, the ideology-visual discourse connection was explored and discussed for the socialist period in picture postcards (Ilovan, 2019, 2020c, 2020d; Ilovan and Maroși, 2018; Merciu, Ilovan and Cercleux, 2020; Merciu, Cercleux and Merciu, 2021) and in comics for communist pioneers (Ilovan, 2020a, 2021a, 2021b). At the international level, the relationship between ideology and representations in picture postcards was paid much attention, as picture postcards are considered a "reservoir of high memorability", because they "reflect and shape particular discourses about place and identity" (Vibha, 2009, p. 57; cf. also Ferguson, 2006; Laakso and Östman, 1999, 2001; Mârza, 2018; Winiwarter, 2008).

Our interpretation of images from the two sources (i.e. school textbooks and postcards) as visual representations draws heavily on the auteur theory which underlines that: "the most important aspect in understanding a visual image is what its maker intended to show" (Rose, 2014, p. 16). However, there are also researchers who argue that the "wider visual context is more significant for what the image means than what the artists thought they were doing" (Rose, 2014, p. 26, quoting Barthes, 1977, pp. 145-146), as with poststructuralism attention shifts from author to reader or interpretant, that is to a never-ending production of meanings (cf. Banini, 2019, pp. 97-112).

In the case of images produced under a totalitarian regime and where censorship controlled cultural production and educational resources, we consider that also this wider context, where the images circulated and were viewed, was under the direct 
influence of the totalitarian state and its control mechanisms (cf. Verdery, 1991; Zahariade, 2011). Thus, the state aimed to control the site of production, the image contents, and the site of audiencing.

Visual discourses of socialism and modernization continue to leave their marks on postsocialist Romania and its citizens. Therefore, postsocialism can be defined also as effects and material and immaterial traces of socialism that are still present (cf. Gibert and Peyvel, 2020, p. 263). The socialist legacy is made of social representations and practices (Gibert and Peyvel, 2020, p. 278), where space is a social product or construct: "ideas about ways of living, achieving social order, and assigning meaning to urban spaces transcend political and economic transformation, and can also outlast socialist-era space. Individuals can embody socialist-era ideas and values for decades and those values can be redeveloped in the interest of post-socialist regimes and meaning associated with socialist space can be reassigned and/or reinvented" (Young and Drummond, 2020, p. 308).

The traces of the socialist legacy are visible in post-socialist Romania. Future "appropriate" opportunities for development and the creation of the highly needed development strategies (Zotic and Alexandru, 2015) are influenced by how Romanians represent space for themselves and how they perceive it (cf. Niţă, 2021), and that is why our study is not only filling a gap in research about representations of socialist territorial development, but it is also necessary for present day creation of policies.

To sum up, our hypothesis is that certain Romanian institutions (i.e. the mass-media, the school) mobilized a certain visuality that allowed political power, through representations, to order life and make a hierarchy of values and places in socialist Romania, imposing from above and advertising a particular way of seeing the world and its relation to modernization (i.e. through an ideological lens).

This dominant visuality produced knowledge, correct visual cognition and organizing of information (Hayles, 2006, quoted in Rose, 2014, p. 10). Ways of seeing the world, produced, and reproduced through generations can have social effects (cf. Banini and Ilovan, 2021a, 2021b), that is why a study on socialist visual representations of Romania is significant also in its post-socialist context.

\section{METHODOLOGY}

\subsection{Study area}

The Danube is the second longest river of Europe $(2,858 \mathrm{~km})$, after the Volga. It flows towards the south-east, down to the Black Sea. The inferior sector of the Danube is on the territory of Romania, being 1,075 km long (Ghinea, 2002, p. 555) and creating the Danube Delta. In Romania, in the Danube Meadow, there are many settlements among which eighteen cities (Moldova Nouă, Orşova, Drobeta-Turnu Severin, Calafat, Corabia, Turnu Măgurele, Zimnicea, Giurgiu, Oltenița, Călăraşi, Fetești, Cernavodă, Hârșova, Brăila, Galați, Isaccea, Tulcea, and Sulina). Our study area excludes the Danube Delta (because it would need special attention in a standalone study), thus remaining the sector from Baziaş to Galaţi (Table 1, Fig. 1).

Table 1. Settlements on the banks of the Danube, in the Romanian sector, down to the Danube Delta (but excluding this).

\begin{tabular}{|c|l|l|}
\hline No. & Settlement & \multicolumn{1}{c|}{ Location } \\
\hline 1 & Baziaş & Village in Socol commune; in its area, the Danube enters the Romanian territory \\
\hline 2 & $\begin{array}{l}\text { Modova } \\
\text { Nouă }\end{array}$ & $\begin{array}{l}\text { Town, within the Danube Defile, in the homonymous depression, at 250-300 m altitude, on } \\
\text { the left of the Danube Valley, at the border with Yugoslavia (during socialism, and with Serbia } \\
\text { at present). River harbour }\end{array}$ \\
\hline 3 & $\begin{array}{l}\text { Orşova } \\
\text { gulf, in the area where the Cerna flows into the Danube, at 29 km north-west of Drobeta Turnu } \\
\text { Severin. When creating the Iron Gates I accumulation lake, the old area of the town was } \\
\text { flooded, and the population was moved to a new area, on the terraces of the Danube, of the } \\
\text { Cerna river and on the southern slope of the Almăj Mountains, where the authorities built a } \\
\text { new town from scratch (1966-1971), including the villages Jupalnic, Tufări, and Coramnic }\end{array}$ \\
\hline 4 & $\begin{array}{l}\text { Turnu } \\
\text { Severin }\end{array}$ & $\begin{array}{l}\text { Municipium, county residence, situated where the Danube exits the Iron Gates Defile, on the } \\
\text { shore of the accumulation lake Iron Gates I, at 65 m altitude, at the border with Yugoslavia, at } \\
\text { present with Serbia. River harbour }\end{array}$ \\
\hline 5 & Calafat & $\begin{array}{l}\text { Municipium, on the left of the Danube, in the west of the Desnăţui Plain, at the border with } \\
\text { Bulgaria. River harbour and border point for crossing the Danube with the ferry }\end{array}$ \\
\hline 7 & Bechet & $\begin{array}{l}\text { Town, in the large meadow on the left of the Danube, at the border with Bulgaria. River } \\
\text { harbour and customs point (border point for crossing the Danube with the ferry) }\end{array}$ \\
\hline 8 & Turnu & $\begin{array}{l}\text { Town, 8o km south of Slatina municipium. River harbour } \\
\text { Municipium, at the southern fringe of the Boian Plain, at 23-29 m altitude, downstream the }\end{array}$ \\
\hline
\end{tabular}




\begin{tabular}{|c|c|c|}
\hline & Măgurele & $\begin{array}{l}\text { confluence of the Danube with the Olt, at the border with Bulgaria, } 50 \mathrm{~km} \text { south-west of } \\
\text { Alexandria and } 135 \mathrm{~km} \text { south-west of Bucharest. River harbour and customs point since } 1860\end{array}$ \\
\hline 9 & Zimnicea & $\begin{array}{l}\text { Town, in the south of the Boian Plain, at } 48 \mathrm{~m} \text { altitude, and } 48^{\circ} 37^{\prime} \mathrm{o} 7^{\prime \prime} \text { northern latitude (being } \\
\text { the southernmost point of Romania), at } 42 \mathrm{~km} \text { south of Alexandria municipium, at the border } \\
\text { with Bulgaria. River harbour and customs point since } 1860\end{array}$ \\
\hline 10 & Giurgiu & $\begin{array}{l}\text { Municipium, county residence, in the south of the Burnas Plain, at } 25 \mathrm{~m} \text { altitude, } 65 \mathrm{~km} \text { south } \\
\text { of Bucharest, opposite to Ruse town (Bulgaria). River harbour and customs point }\end{array}$ \\
\hline 11 & Olteniţa & $\begin{array}{l}\text { Municipium, downstream the confluence of the Danube with the Argeş, at 5-15 } \mathrm{m} \text { altitude, } 60 \\
\mathrm{~km} \text { south-east of Bucharest. River harbour }\end{array}$ \\
\hline 12 & Călăraşi & $\begin{array}{l}\text { Municipium, county residence, in the south-eastern part of the Romanian Plain, on a terrace } \\
\text { on the left of Borcea river branch (of the Danube), at } 25 \mathrm{~m} \text { altitude, river harbour, point for } \\
\text { crossing the Danube to Constanţa County, with the ferry }\end{array}$ \\
\hline 13 & Cernavodă & $\begin{array}{l}\text { Town, in the west of the Carasu Tableland, on the right of the Danube and on the left of the } \\
\text { Danube-Black Sea Canal, } 65 \mathrm{~km} \text { west-north-west of Constanţa municipium. River harbour }\end{array}$ \\
\hline 14 & Hârşova & $\begin{array}{l}\text { Town, in the west of the homonymous tableland, on the meadow and terrace on the right of } \\
\text { the Danube, } 85 \mathrm{~km} \text { north-west of Constanţa. River harbour }\end{array}$ \\
\hline 15 & Feteşti & $\begin{array}{l}\text { Municipium, in the east of Bărăgan Plain, on the left of Borcea river branch, } 55 \mathrm{~km} \text { south-east } \\
\text { of Slobozia municipium. River harbour }\end{array}$ \\
\hline 16 & Măcin & $\begin{array}{l}\text { Town, in the north-west of Dobrudja, at the foot of the Măcin Mountains, on the right of Măcin } \\
\text { river branch, } 77 \mathrm{~km} \text { west-north-west of Tulcea municipium. River harbour }\end{array}$ \\
\hline 17 & Brăila & $\begin{array}{l}\text { Municipium, county residence, in the north-east of the Brăila Plain, at } 20 \mathrm{~m} \text { altitude and } 170 \\
\mathrm{~km} \text { upstream from where the Danube flows into the Black Sea. River and sea harbour up to } \\
\text { which big ships can sail }\end{array}$ \\
\hline 18 & Galaţi & $\begin{array}{l}\text { Municipium, county residence, in the south-east of the Covurlui Plain, on three terraces of the } \\
\text { Danube, at 4-35 m altitude, } 7 \mathrm{~km} \text { downstream the confluence of the Siret with the Danube, and } \\
150 \mathrm{~km} \text { upstream from where the Danube flows into the Black Sea. River and sea harbour (7- } \\
10 \mathrm{~m} \text { sea gauge downstream) }\end{array}$ \\
\hline
\end{tabular}

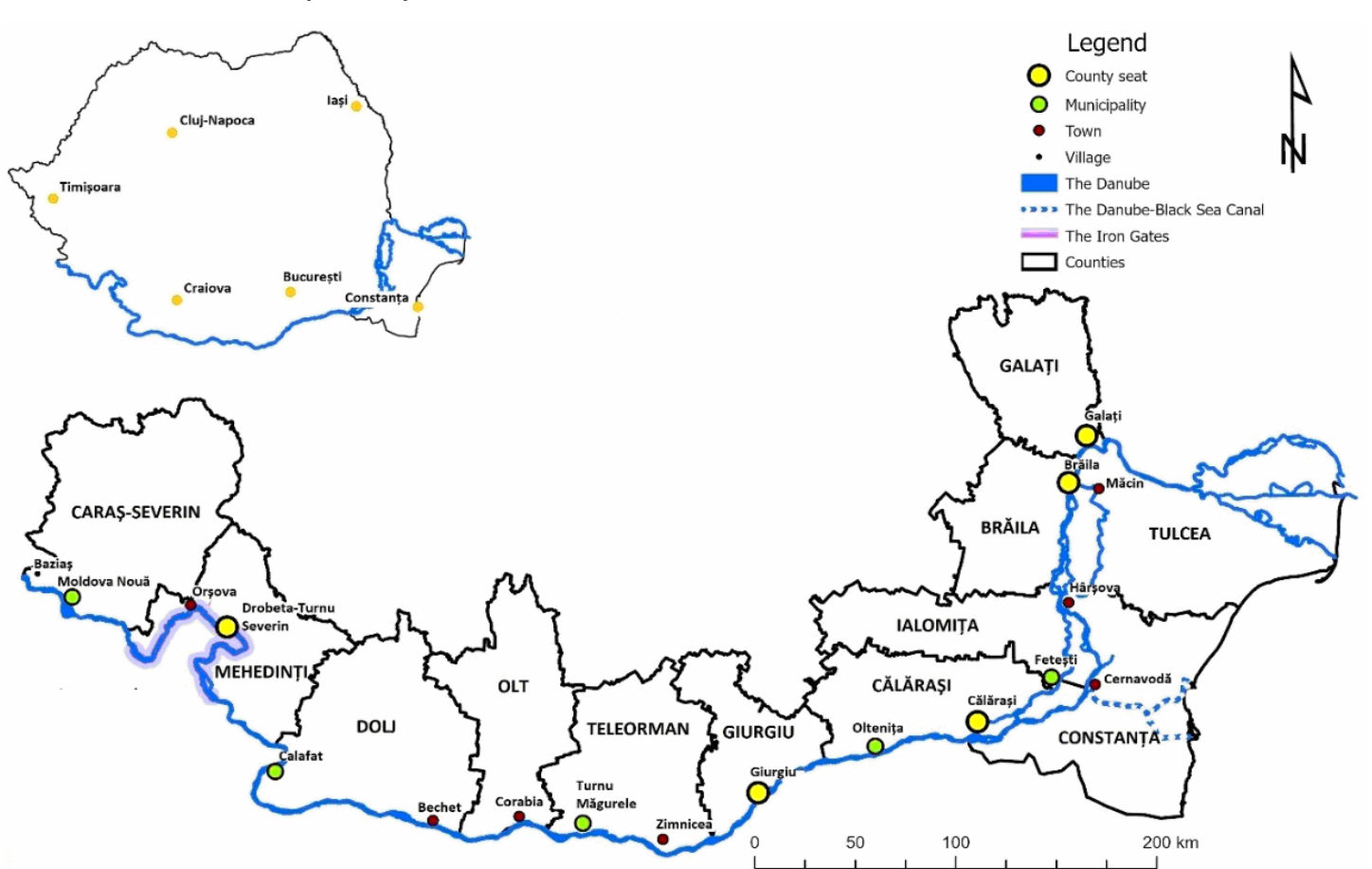

Fig. 1. Study area: Settlements on the banks of the Danube, in the Romanian sector (excluding those in the Danube Delta).

The Danube collects most of the rivers of Romania except for some from Dobrudja. It is also highly significant for navigation, electricity production, fishing, and supplying water to population, agriculture, and industry (Posea, Bogdan and Zăvoianu, 2005; Vijulie et al., 2019). 
Oana-Ramona ILOVAN, Florentina-Cristina MERCIU

Journal of Settlements and Spatial Planning, Special Issue, no. 7 (2021) 15-50

Territorial Identities and Heritage. Discourses and Practices

\subsection{Data collection}

Here we include a brief presentation about the process of finding our visual materials. The primary sources for our research are photographs and related text in school textbooks and picture postcards during socialist Romania (1948-1989). We considered the relation images in picture postcards had with other images from other media. For this research, we chose the photographs in Geography of Romania school textbooks (more likely to be discussing territorial development than textbooks of other school subjects). We argue that this relation is based on content, and even on explicit cross-referencing, as, frequently, textbooks involved exercises where the use of picture postcards and other illustrations was recommended (Iancu, Motrescu and Negulescu, 1985; Iancu, Motrescu and Florescu, 1989; Giurcăneanu, Muşat and Ghica, 1986). Besides the content-based relation, these images established also a relation based on a shared location of display or viewing/reading: the school.

Still images on commercial websites in the form of scanned picture postcards were collected during December 2020 and January 2021, considering the pros and cons of sourcing, and using online databases, for visual materials (for more details about this, cf. Bertram, 2010 and Rose, 2014, pp. 328-344). In this article, we reproduce only images in picture postcards from our collections, although a larger number of picture postcards were sourced from commercial sites and analysed. We analysed approximately 500 picture postcards. These images illustrate our argument and can have their own agency; therefore, we include a selection to enable the readers of this article to interact with them while reading. The secondary sources are books and articles on the theme of working with representations and on the topic of socialist Romania.

For postcards, we looked for the name of the photographer who took the picture in order to mention correctly the authorship, but we did not consider this information to have any significant bearing on the image, because of the ideological context photographers had to work in and because their selection of sites and objects to be photographed was not a personal choice. Political prescriptions narrowed down the repertoire of photographers in order to produce certain kinds of images. Then, we looked for the date, to be able to place the picture postcard during the period, the title, and the publishing house. The title gave us information about the represented places and could make differences in the interpretation of the image. However, not all images were titled, or the title was too general (e.g. name of the city/town and "a view"). The criteria for choosing the collages were: at least one representation of the Danube and representations of territorial development. We grouped postcards by settlements, and we created two separate folders for the Iron Gates and the Danube20
Black Sea Canal. We found the highest number of postcards for the city of Galaţi.

We aimed to analyse picture postcards not only through what they illustrated, what they offered for viewing, but also by the seeing they invited. We argue that inviting particular ways of seeing can educate the spectators' visuality on a long term. Thus, we decided to select collages, or stories in images. The Danube is not a ubiquitous element of the collages, that is why we had to look for the ones which included its representations. We contextualised and, in fact, annotated these in picture postcards with other images on the same topic from Geography of Romania school textbooks and with their related text.

Four Geography of Romania school textbooks have been analysed: two for the $4^{\text {th }}$ grade (Iancu, Motrescu and Negulescu, 1985; Iancu, Motrescu and Florescu, 1989), one for the $8^{\text {th }}$ grade (Giurcăneanu, Muşat and Ghica, 1986), and one for the $12^{\text {th }}$ grade (Tufescu, Giurcăneanu and Mierlă, 1981). All of them are from the 1980 s, the last decade of socialist Romania. We used these based on availability and since they were later editions of previous textbooks and most likely to present the latest and many achievements of the socialist nation. Besides these textbooks, several methodics of geography from the socialist period of Romania were analysed (Ardeleanu et al., 1964; Dăneț, Enache and Olănescu, 1984; Mândruţ, Ungureanu and Mierlă, 1982), considering the provided didactic advice about the use of visual imagery in the lessons on the Geography of Romania.

\subsection{Data processing}

Images, likewise maps, are very strong statements. When working with visual imagery, we kept in mind that "numbers do not translate easily into significance" (Rose, 2014, p. 102), and that is why we used qualitative analysis. There is no assurance that what occurs more often is necessarily more significant than what occurs more seldom or than what is omitted on purpose.

In our interpretative work of images (cf. Crang, 2010) from the two above-mentioned media, we used the method of discourse analysis. We employed discourse analysis (cf. Dittmer, 2010), which is a semiological method, on the two visual imagery types: photographs in school textbooks and picture postcards. The interpretative possibilities offered by discourse analysis helped us decide to choose it in order to uncover how meanings were made. To make this method work well, we first looked for contextual knowledge about the visual imagery we worked with: the production of textbooks and methodics of geography available for teachers when using these and the production of picture postcards in socialist Romania. There is very little information about the 
production of images in the two sources in order to understand how the context might have influenced meaning construction during their reading.

However, much of the ideological content of these representations is particularly easy to read. Because we analysed the visual discourse proposed by picture postcards, in this article, we did several finegrained readings of meaning-making instances for a series of picture postcards, and we used collages to show how the story was presented by means of using montage. A montage was used to enable viewers adopt the point of view and way of reading of the author of that composition. Montage is "a term related to the composition of moving images, and refers to the temporal organization of a film [...] montage is how those shots are put together, that is, how they are presented" (Rose, 2014, p. 71).

We selected collages, we identified their elements (the symbolism of individual images) and the relationships among them. These collages produce narratives in spatial coherent representations as they refer to well-established territorial units (i.e. a town, a city, or a county). The narrative structure, as in the case of comics, can be read from left to right and from the top to the bottom of the collage, and this is sometimes made explicit by numbering the photographs, on the back of the postcard, for the sake of naming what they present. However, the viewer can create his or her narrative structure when looking at a picture postcard collage and thus there are several possibilities of composing the narrative.

"All knowledge is vulnerable to semiological reinterpretation" (Rose, 2014, p. 107) and so are the included images analysed in this article. As semiology proved to be a useful method for critical visual analysis of advertisements and we considered images in textbooks and picture postcards as an uncostly and powerful form of advertising contemporary achievements, we used semiology for uncovering the making of meaning in these representations as they presented a certain version of the socialist world: the official visual discourse.

The theoretical framework of semiotics as a method for analysing visual representations is necessary when we consider representations to be collections of relevant signs. Thus, the basic unit of language is the sign. This consists of two parts, which are arbitrarily connected: the signified (concept or object) and the signifier (the sound or image attached to the signified). The sign relates to the referent, which is the actual object (de Saussure, 1986; according to de Saussure, the signifier coincides with the object of representation, and corresponds to one, absolute, unique signified or meaning).

In addition to de Saussure, the American philosopher Charles Sanders Pierce developed a typology of signs which is useful when working with symbols. According to Pierce, "symbolic signs have a conventionalized but clearly arbitrary relation between signifier and signified" (Rose, 2014, p. 119). What is particularly useful in Pierce's distinguishment between paradigmatic and syntagmatic signs is that signs do not get significance only on their own, but also in relation to other signs (i.e. that surround them in the image). We argue that a syntagmatic relationship is in place between the images of the picture postcard collage. Moreover, extrameaning is gained by those signs that appeared in previous representations (in other images, from the same or other media).

We interpreted the signs (elements) composing these images and this enabled us to look carefully at the contents of the images in one postcard collage and the signified relationships among them. As forms of advertising development and territorial prestige based on a variety of resources, picture postcards, likewise advertisements, were at the core of structuring Romanians' ways of seeing. Other texts, carrying the same or similar messages (like school textbooks), reinforced ideological meanings and interpretations, forming a visual ideology of the period and visual intertextuality.

We analysed the images in collages individually and then collectively, as part of a group of representations whose meaning was constructed relationally. For these images, representational significance changed when used in collages than single standing. They are to be read in connection with the other images in the respective story (i.e. collage). The positioning of the images in the collage, their size and the relationship with the other images reflect their political, economic, and social links within socialist Romania. Our question was: How do collages (to be read "visual narratives") relate to other collages in producing the narratives about socialist development?

Captions for picture postcards are a key device in producing meaning in a certain way. Objects, subjects, and subjectivities are produced in the framework of a particular visuality (i.e. way of seeing). The readers of this article may experience the visuality that we, as authors, propose, by interacting with the titles we gave to the figures (besides the original title of the figures in school textbooks and of the respective picture postcards).

The cultural context helps making sense of the meaning of signs and of their potential meanings when in connection with more information or certain types of information from the respective cultural context. This context provides the image with a cultural anchorage, the same way the word-text provides the image with the necessary anchorage allowing the reader to choose from the potential denotative meanings. This image-written text complementarity was named the relay-function (Barthes, 1977, pp. 38-41). Content analysis is the first empirical step made in analysing these photographs, in 
order to get a sense of what they showed. The analysis of visual materials is first realised, then of the accompanying text, and finally of the relationship between image-text and word-text. This is an "important reminder that nothing is ever just visual, and that all visual images are accompanied by other kinds of semiotic resources that are integral to their meaning" (Rose, 2014, p. 139).

Concerning textbooks, our discourse analysis focused on images and language anchoring the messages of the respective visual imagery, using semiology also as a complementary method of uncovering/de-constructing the meanings of these visual materials (to be read as "understanding", as meaning is not laid to be received, but it is constructed in the process of viewing/reading). Therefore, we paid careful attention to images themselves and to the connected materials that enabled our decoding. Through discourse analysis, we explored how accounts of territorial identities for Danubian settlements were constructed as real, and these representations became authoritative accounts. Knowledge about these settlements is produced through the compilation of images and their meanings.

The books of didactics of geography may be interpreted too as documents that show the relationship between state education authorities (the ministry, the commissions working on the development of the curriculum and textbooks) and the act of teaching.

\section{RESULTS AND DISCUSSIONS}

This section includes six parts, focusing on the results of our semiotic and discourse analyses of the research material. First, we read territorial identity for the Danube and the Romanian Danubian settlements in Geography of Romania school textbooks, secondly, we contextualised the use of images in picture postcards in Romania, and thirdly, we presented the most frequent representations in picture postcards for the Romanian Danubian settlements.

Next, we presented and discussed the territorial identity stories of the Danubian settlements based on a selection of picture postcard collages and we reflected on interacting with representations and on the "misreading" of official visuality, by giving an example. Finally, we discussed visual intertextuality and the discourse in school textbooks and picture postcards.

\subsection{Reading territorial identity for the Danube and the Romanian Danubian settlements in Geography of Romania school textbooks}

In this part, we analyse the visual representations of the Danube and of Romanian Danubian settlements in Geography of Romania school textbooks from the socialist period. School textbooks offer authoritative accounts of the socialist reality on all dimensions of life. The school claims to inform and educate. This function is performed with the help of the school textbooks. The four selected school textbooks provided us with representations of the high socialist period of Romania: the dismantling of the previous capitalist system was celebrated through achievements that were the results of socialist reforms; heavy industrialisation was represented through factories and industrial platforms.

In Geography of Romania school textbooks of the period, the ideological discourse on development was structured in persuasive word-text and accompanying images having the function to illustrate arguments. The written and visual narratives of socialist economic progress were backed up by statistical data. In the case of picture postcards, viewers are relatively free in their use of these visual materials, but this is not so for the other resource: school textbooks. Considering that "the use of semiotic resources is heavily shaped by the established meanings of those resources" (Rose, 2014, p. 141), we argue that representations are part of an education process and thus intrinsic to the people who interacted with them.

Geographical education, propaganda and economic progress were connected through the then and now discourse, which is ideologically relevant. As methodics of geography underlined (Ardeleanu et al., 1964; Dăneț, Enache and Olănescu, 1984; Mândruț, Ungureanu and Mierlă, 1982), a key relationship should be shaped between geographical education and patriotism. Therefore, propaganda information was meant to be transmitted about the achievements of the socialist system: "One should insist on the most recent industrial achievements, also showing the future development perspectives (The Iron and Steel Factories in Galați [...])" (our transl., Ardeleanu et al., 1964, p. 159).

In addition, propaganda information should have been received through mass-media, besides the classical school textbook:

"Informing themselves from the lecture of newspapers and radio-TV broadcasting presents aspects such as: on the high run-off rivers (Olt, Argeș, Bistrița, Siret, Cerna, etc.), they have built and are still building tens of hydropower plants; in many centres they build numerous industrial objectives; Bucharest metro is being built; they built the Danube-Black Sea canal; in the country, they modernise roads, they increase the surface of the plantations for fruiters and vineyards, etc., about which the geography school textbooks will not write only after a number of years. Only through scanning the newspapers, one may understand how are achieved the great objectives envisioned in the development plans of socialist Romania, why it matters to be economical with resources, the commercial and cultural exchanges of our country, how our Party's and state's policy is asserted daily in the international 
sphere, how the friendship relationships are realised between our state and other states, which are the principles that form the basis of these relations" (our transl., Dăneț, Enache and Olănescu, 1984, p. 45).

Methodics of geography pointed out that using visual materials was a means of modernising education. First, maps were considered true images of the homeland, on which the Danube was among the landmarks, due to its border function, but also a representative geographical element of Romania alongside the other major rivers:

"Thus, a student who graduates high school should interpret correctly, for instance, a climatic map, a land use map, an economic map. But this requires that teachers be more concerned in familiarizing students with such maps, that are, in fact, various 'images' of the homeland; the maps in the 'Atlasul Național al R. S. România' [National Atlas of the Socialist Republic of Romania] are very useful and suggestive from this point of view. We consider that a skill that should be formed progressively during school years, but which should be accomplished in the $12^{\text {th }}$ grade, is that students are able to sketch independently the contour of our country and several landmarks (the Danube, the main rivers). Based on experience, we can appreciate that forming this skill does not raise difficult problems, on the condition that it is frequently practiced during lessons" (our transl., Mândruţ, Ungureanu and Mierlă, 1982, p. 15). Thus, textbooks include activities whose revision consisted of working with the map or writing a text, using images to illustrate it. The focus of these activities on territorial development (either natural or anthropic) is obvious:

"Write an essay on one of the following topics. Find images (illustrations) that you glue within your paper: 'The Danube Delta, the youngest Romanian land'; 'Danube, Danube - dustless way' [...]" (our transl., Iancu, Motrescu and Negulescu, 1985, p. 126).

In this educational context, we approach the visual discourse about the Romanian sector of the Danube and of the Danubian settlements (excluding the Danube Delta) based on four Geography of Romania school textbooks (Table 2).

Table 2. Photographs of the Danube and of Danubian settlements in the Geography of Romania school textbooks, the 1980 s. $^{*}$.

\begin{tabular}{|c|c|c|c|c|}
\hline No. & $\begin{array}{c}4^{\text {th }} \text { grade textbook } \\
(1985) \text { (out of } 47 \\
\text { photos) }\end{array}$ & $\begin{array}{c}4^{\text {th }} \text { grade textbook } \\
(1989)^{* *} \\
\text { (out of } 22 \text { photos) }\end{array}$ & $\begin{array}{c}8^{\text {th }} \text { grade textbook } \\
(1986) \text { (out of } 49 \\
\text { photos) }\end{array}$ & $\begin{array}{c}12^{\text {th }} \text { grade textbook } \\
(1981) \text { (out of } 15 \\
\text { photos) }\end{array}$ \\
\hline 1 & The new town Orşova & $\begin{array}{l}\text { The Danube-Black Sea } \\
\text { Canal }\end{array}$ & $\begin{array}{l}\text { Orşova - the new town } \\
\text { built on the shores of the } \\
\text { Iron Gates I Lake }\end{array}$ & $\begin{array}{l}\text { Iron Gates Hydropower } \\
\text { Plant }\end{array}$ \\
\hline 2 & $\begin{array}{l}\text { The Iron Gates - "Iron } \\
\text { Gates I" hydro energy and } \\
\text { navigation system. } \\
\text { Grandiose works realised } \\
\text { by our country in } \\
\text { collaboration with the } \\
\text { Socialist Federative } \\
\text { Republic of Yugoslavia }\end{array}$ & $\begin{array}{l}\text { With the ship on the } \\
\text { Danube }\end{array}$ & $\begin{array}{l}\text { Iron Gates I Hydropower } \\
\text { Plant }\end{array}$ & $\begin{array}{l}\text { Steel and Iron Factories } \\
\text { in Galaţi }\end{array}$ \\
\hline 3 & $\begin{array}{l}\text { Galaţi. Aspect from the } \\
\text { Iron and Steel Factories, } \\
\text { the biggest "fire fortress" } \\
\text { of the country }\end{array}$ & $\begin{array}{l}\text { Galaţi. Aspect from the } \\
\text { Steel and Iron Factories }\end{array}$ & $\begin{array}{l}\text { The Friendship Bridge at } \\
\text { Giurgiu-Ruse - with } \\
\text { railway and road }\end{array}$ & - \\
\hline 4 & - & - & The Danube at Giurgiu & - \\
\hline 5 & - & - & $\begin{array}{l}\text { View from the Steel and } \\
\text { Iron Factories, a } \\
\text { workshop - Galaţi }\end{array}$ & - \\
\hline
\end{tabular}

* All titles of figures mentioned are the original ones (exact phrasing from the textbook, translated into English).

** New photographs in comparison to the 1985 version.

\subsubsection{Image-text relationship in the $4^{\text {th }}$ grade Geography of Romania school textbook, the 1985 edition}

In this textbook, there are three representations which have been already recognized as ideologically relevant for the discourse on Romanian development (cf. Zahariade, 2011, p. 43; Ilovan, 2019, 2020d). The image with the Iron Gates I hydro energy and navigation system (Fig. 2) appears in this textbook in the section on rivers. In addition, explanatory text underlines the importance of this hydrotechnical achievement from multiple points of view: "At the Iron Gates, our country, together with the Socialist 
Federative Republic of Yugoslavia, has built a great hydropower plant. Through the realised works, navigation on this Danube sector is much easier. At present, two big hydropower plants are being built on the Danube: one, named Iron Gates II, that we build with the Socialist Federative Republic of Yugoslavia, and another one at Turnu Măgurele-Nikopol, with the Popular Republic of Bulgaria” (our transl., Iancu, Motrescu and Negulescu, 1985, p. 46).

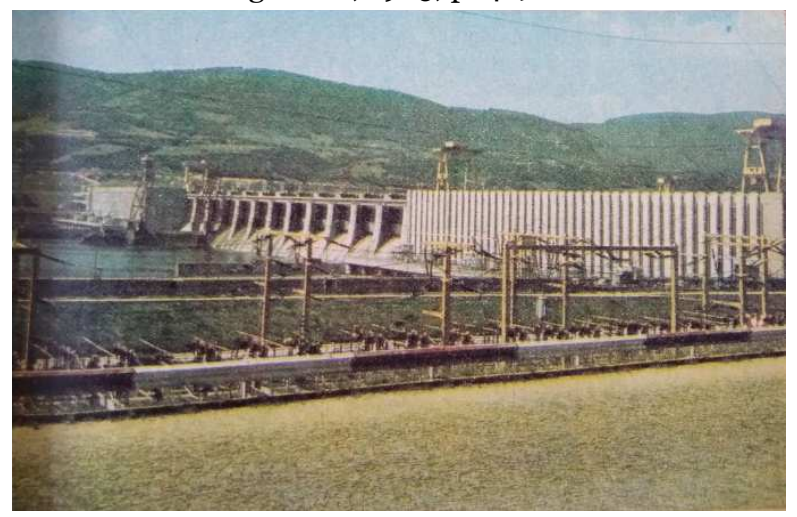

Fig. 2. "Iron Gates I hydro energy and navigation system. Grandiose works realised by our country in collaboration with R.S.F. Yugoslavia" (source: Iancu, Motrescu and Negulescu, 1985, p. 28).

"In truth, if the tourist walks on the shadowy paths of the Carpathian Mountains, he will meet fairytale places: such as the Bicaz, Dâmbovicioarei and Turzii Gorges, where the man of our time has dammed the torrential waters of the Bistriţa at Bicaz, the crystal waters of the Arges at Vidraru, of the Lotru at Vidra, of the Danube at the Iron Gates [...]" (our transl., Iancu, Motrescu and Negulescu, 1985, pp. 115-118).

Moreover, the political, symbolic, and ideological relevance of this objective is underlined by architects analysing the socialist era architecture:

"Industrial architecture not only remained at the heart of communist economic ideology, but also it could sometimes be endowed with additional symbolic connotations. For example, the huge steel mill at Galați or the Iron Gates hydroelectric plant were meant to boost Gheorghiu-Dej's 'dissident' economic policy, challenging Moscow and the COMECON" [The Council for Mutual Economic Assistance] (Zahariade, 2011, p. 43).

The new town of Orşova (the result of its rebuilding in the new location) is represented. Orşova is included along the textual representation for the Western Carpathians. It seems uninhabited from the angle it is photographed (Fig. 3).

No people or movement, the street is empty, but we may imagine that there are people because of the two parked cars and the many blocks of flats. No people at the Iron Gates I either, but monumental industrial architecture (see Fig. 2). Industrial platforms and industrial architecture were given priority in representations as well as any related landscape changes, as underlined by Zahariade: "these buildings and industrial installations brought about spectacular changes in the physiognomy of the natural landscape"; "one of the most spectacular terra-forming operations was the submersion of Ada Kaleh Island and the relocation of the city of Orşova to make way for the Iron Gates hydroelectric plant on the Danube" (Zahariade, 2011, p. 42).

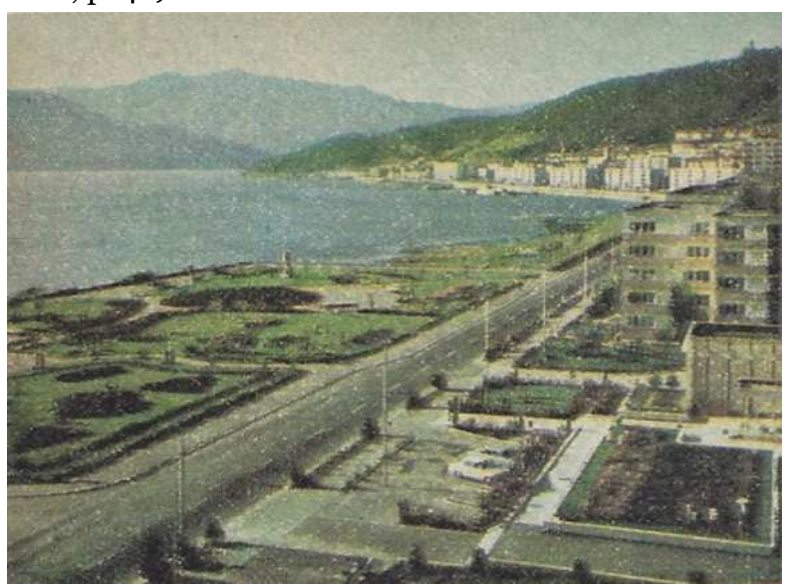

Fig. 3. Amorphous mass-housing in new Orşova: "The new town Orşova" (source: Iancu, Motrescu and Negulescu, 1985, p. 47).

Also the image on the first cover of this textbook represents Romania through its industrial and technical achievements (constructions, a dam, chemical and heavy industry, electrification of the country, a boat) (Fig. 4).

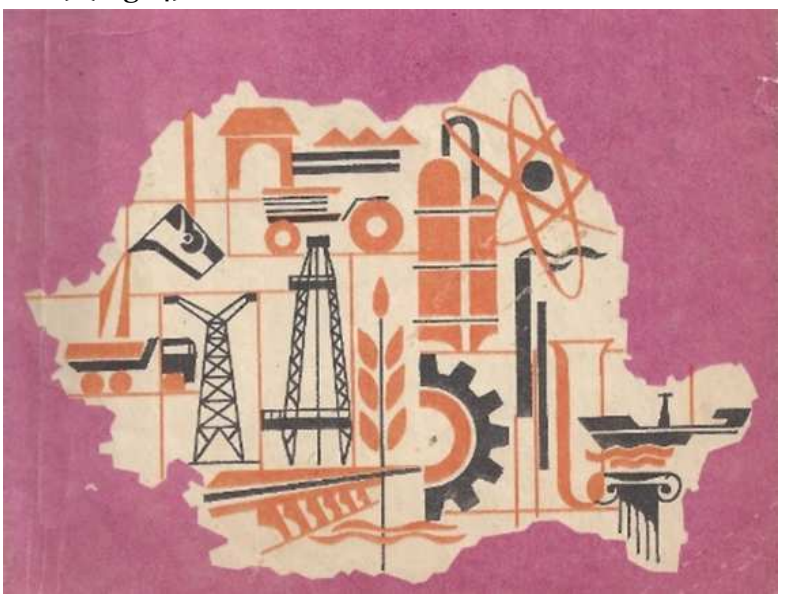

Fig. 4. Front cover of the 4 th grade textbook (source: Iancu, Motrescu and Negulescu, 1985).

These symbols are distributed (at least some of them) to refer to the location of certain development achievements in their respective regions. Forestry and wood architecture is symbolised for northern Romania - Maramureş. The dam in the south refers to the hydropower plant of Iron Gates I, the boat is overlapping Dobrudja due to its neighbouring the Black Sea and the Danube Delta, etc. (Fig. 4).

At the section about rivers, authors present an organic image of the entire Romanian territory induced by the features of the hydrographical network, compared with a functioning mechanism evoking unity: 
"Almost all big rivers spring from the Carpathians, and from there they head in all directions, like the rungs of a huge wheel, and flow into the Danube, which, in its turn, flows into the Black Sea" (our transl., Iancu, Motrescu and Negulescu, 1985, p. 45).

And this unity of the Romanian territory is very old because: "Many songs and legends speak about the Danube" (our transl., Iancu, Motrescu and Negulescu, 1985, p. 45). The tributaries of the Danube their features are listed and where hydropower plants are built (Iancu, Motrescu and Negulescu, 1985, pp. 4849) - are described considering their usefulness in providing the necessary electricity for the urban area and enabling the development of the irrigation system: "in the Danube Meadow and in the meadows of the rivers, they will continue the action of taking out of the floodable area important surfaces of land that will be given to agriculture. [...] As a result of these measures, the agricultural production of our country increases more and more" (our transl., Iancu, Motrescu and Negulescu, 1985, pp. 98-99).

Industry is represented in nine photographs and one is of Galaţi, in black and white, with the Iron and Steel Factories (Fig. 5).

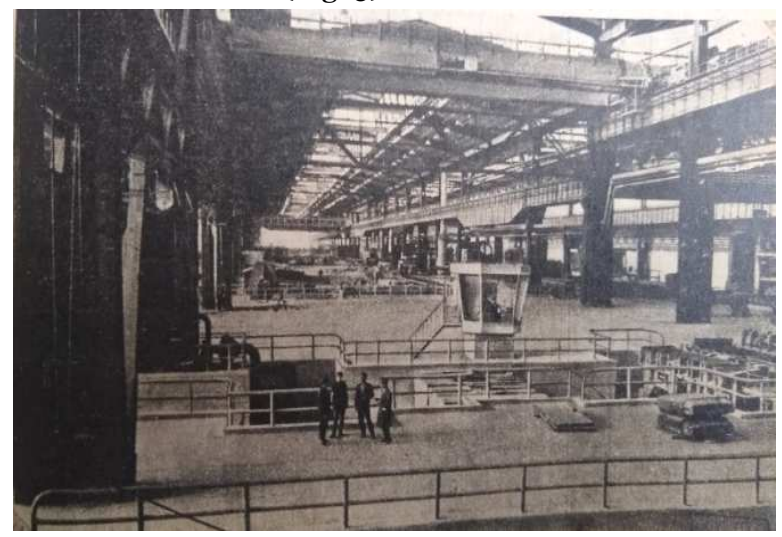

Fig. 5. Huge production hall with working people in the foreground: "Galaţi. Aspect from the iron and steel factories, the biggest 'fire fortress' of the country" (source: Iancu, Motrescu and Negulescu, 1985, p. 79).

At the beginning of the 1960s, starts the building of the Iron and Steel Factories in Galați, the biggest in Romania; these will become the symbol of socialist Romania, associated with industrial independence from the U.S.S.R. In 1967, they are functional: "The biggest iron and steel centres of our country are in Galaţi, where, during the years of socialism started to function the biggest iron and steel factories of our country. In recent years, new iron and steel platforms have appeared on the map of our country: Tîrgovişte, Călăraşi, Buzău, Iaşi, etc. (our transl., Iancu, Motrescu and Negulescu, 1985, p. 81).

One can notice the othering of decline within the now and then discourse: decline was not characteristic of the socialist Romanian society. At present, new factories are built nearby Brăila city: “Only in the years of socialist construction the reed received great importance. It is used for producing paper and other products. With this aim, nearby Brăila city, large chemical factories have been built" (our transl., Iancu, Motrescu and Negulescu, 1985, p. 40).

The presence of the Danube is discussed in relation to the industrial activity of the Danubian harbours: "In the harbours of Constanţa, Galaţi, Mangalia, Olteniţa, and Drobeta-Turnu Severin, there are big shipyards where they produce maritime and fluvial ships" (our transl., Iancu, Motrescu and Negulescu, 1985, p. 85).

Transport routes are built or modernised and the Danube is crossed by some of them, testifying the usefulness of socialist constructions: "In the years of socialist constructions, they paved and modernised many roads of our entire country. The bridge over the Danube, between Giurgeni and Vadu Oii, connects by road the capital city and the seaside" (our transl., Iancu, Motrescu and Negulescu, 1985, p. 111).

\subsubsection{Analysis of the photographs in the $4^{\text {th }}$ grade Geography of Romania school textbook, the 1989 edition}

New images are introduced in the 1989 edition of the 4th grade textbook, mainly for the illustration of developmental achievements, proving the political and economic power of the communist regime: The Danube-Black Sea Canal and Dam (Fig. 6).

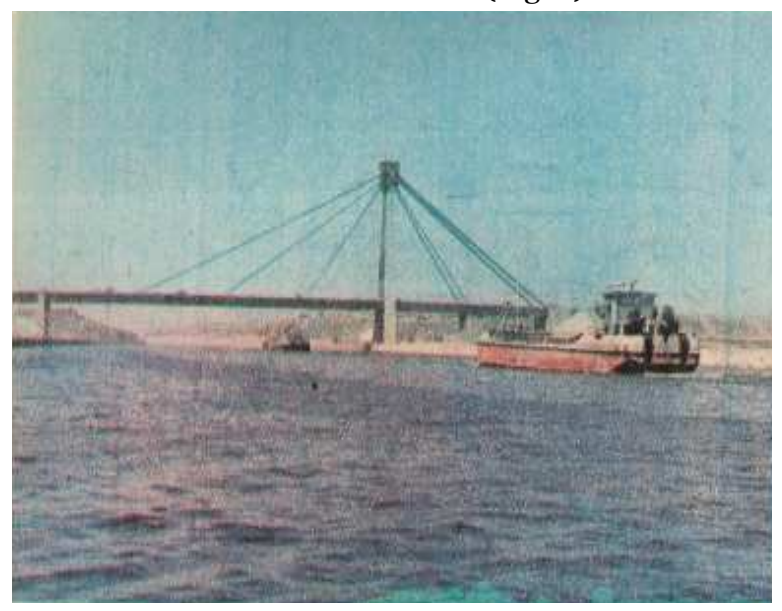

Fig. 6. Grandiose expressions of development - The Canal as the image of punitive socialist order, and heavy industry: "The Danube-Black Sea Canal" (source: Iancu, Motrescu and Florescu, 1989, p. 48).

The Danube-Black Sea Canal (RO, Canalul Dunăre-Marea Neagră) is a navigable canal on the Danube river (from Cernavodă to Constanța and Năvodari). This sailing route mainly on the valley of the Carasu river, which unites the Danube (south of Cernavodă) with the Black Sea (at Agigea-Constanţa South), shortens the route of the ships heading to Constanţa with approximately $400 \mathrm{~km}$ and ensures the irrigation of 200,000 ha of agricultural land. Through 
the Rhine-Main-Danube Canal, it links the North Sea to the Black Sea.

The idea of building a canal in the Dobrudja is quite old. Projects for realising this date back to the $19^{\text {th }}$ century (in 1834, the first measurements are made at the request of sultan Mahmud II, and in 1844, by Austrian engineers and geologists, while that part of the country was still under Ottoman suzerainty), but these were not turned into reality because of their high costs and the needed but unavailable technology. The first Romanian proposal to build a navigable canal between Cernavodă and Constanţa was realised by agronomist Ion Ionescu de la Brad (1818-1891) and dates to 1850, but without any concrete action. The idea is taken up in 1922 by engineer Leon Stoenescu-Dunăre, who offers for public discussion a project for a canal on the Cernavodă-Medgidia-Murfatlar-Valul lui TraianConstanţa route (Ghinea, 2002, p. 347).

The work began in 1949 and, with some interruptions, ended in 1984. In 1949, they started the works for realizing a waterway between Cernavodă and Midia (north of Constanţa). Political prisoners were used as workforce in the 1950s, while deaths are estimated at several thousand because of the inhumane work conditions, of fatigue through forced work. In June 1953, the works to the canal are abandoned because of economic reasons, and the diggings were turned to good account starting with 1959, within "Mircea Vodă Irrigation Complex", later developed as the "Carasu Irrigation System". The project was approved in June 1973, and the construction works begun in the autumn of 1975 were finished in the spring of 1984 (it was opened on the $26^{\text {th }}$ of May 1984 by Nicolae Ceaușescu).

The canal crosses the Southern Dobrudja Tableland, with an altitude under $150 \mathrm{~m}$ in this area and a total length of $64.2 \mathrm{~km}$, allowing for sailing in two directions at the same time. At both ends, the canal has a watergate (one at Cernavodă and another one at Agigea). Along its route, the canal is crossed by seven bridges, out of which one is mixt (road and railway) from Cernavodă (over the watergate), $571 \mathrm{~m}$ long and with a maximum opening of $81 \mathrm{~m}$. The Danube-Black Sea Canal has a $26.6 \mathrm{~km}$ long branch (Poarta AlbăNăvodari-Midia Canal) (Ghinea, 2002, p. 348). The Canal was an iconic construction landmark (see Fig. 6). It had a political and economic symbolism and Ceauşescu triumphed in his position of great architect, visionary, and protector of Romania.

Heavy industry is represented through four new images with factories from renown industrial centres of Romania and one of them is of Galaţi, presenting an industrial landscape (aspect from the Steel and Iron Factories) (Fig. 7).

"With the ship on the Danube" (Fig. 8) is the title of a new image showing maritime transports of passengers.

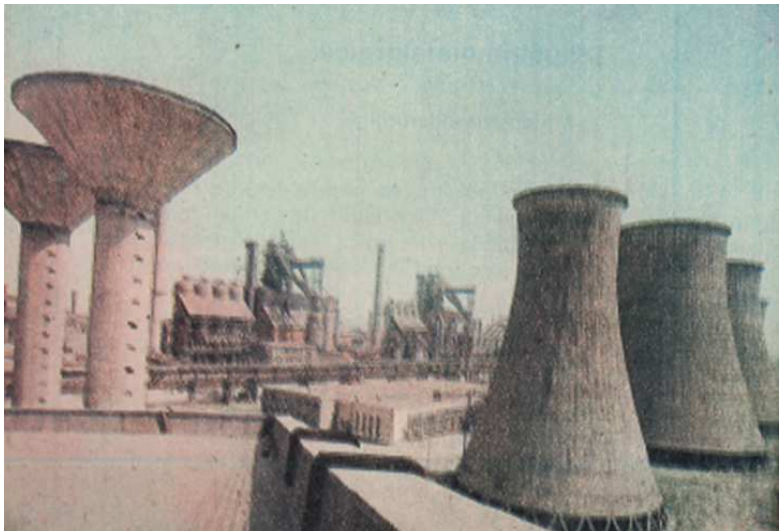

Fig. 7. Grandiose expressions of development: "Galaţi. Aspect from the Steel and Iron Factories" (source: Iancu, Motrescu and Florescu, 1989, p. 82).

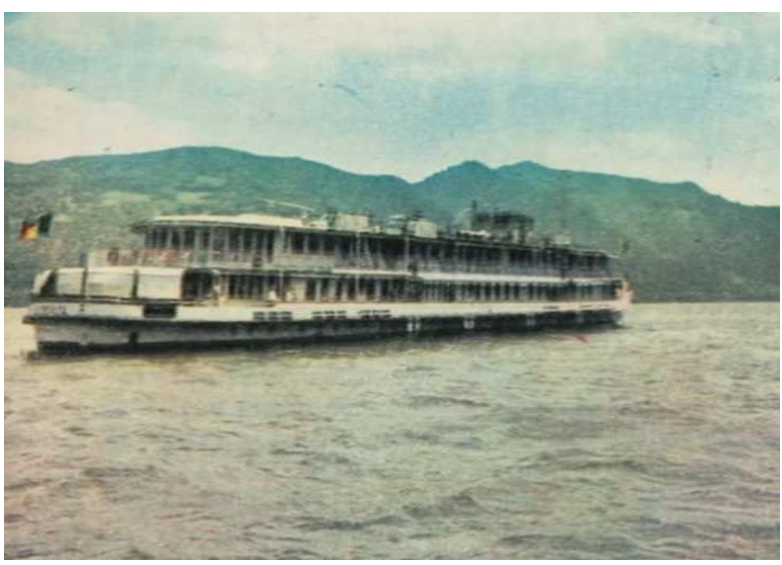

Fig. 8. Danube, a site of leisure: "With the ship on the Danube" (source: Iancu, Motrescu and Florescu, 1989, p. 128).

\subsubsection{Analysis of the photographs in the $8^{\text {th }}$ grade Geography of Romania school textbook, the 1986 edition}

Physical geography topics are illustrated by photographs with the Iron Gates I and the Danube, from our study area. Orşova town is described as the town on the shores of the Iron Gates I Lake (Fig. 9).

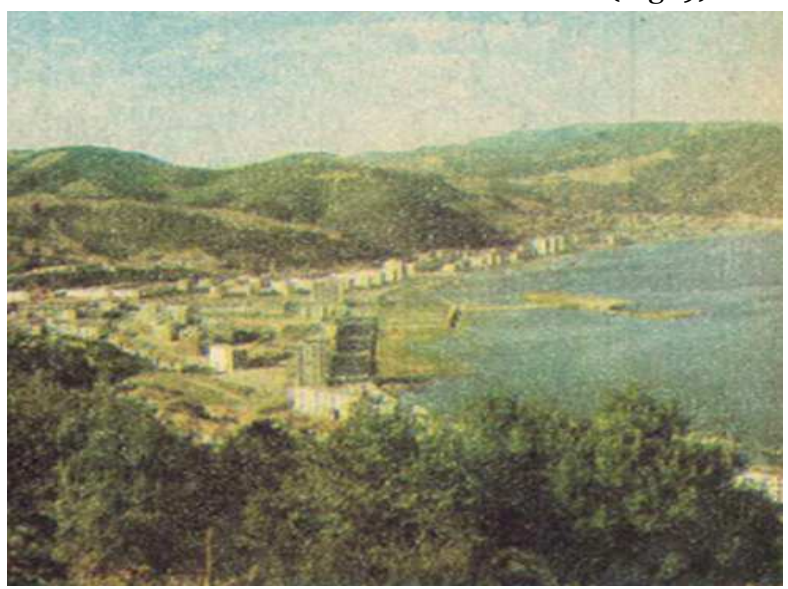

Fig. 9. Development creates new places and proud belonging: "Orşova - the new town built on the shores of the Iron Gates I Lake" (source: Giurcăneanu, Muşat and Ghica, 1986, p. 35). 


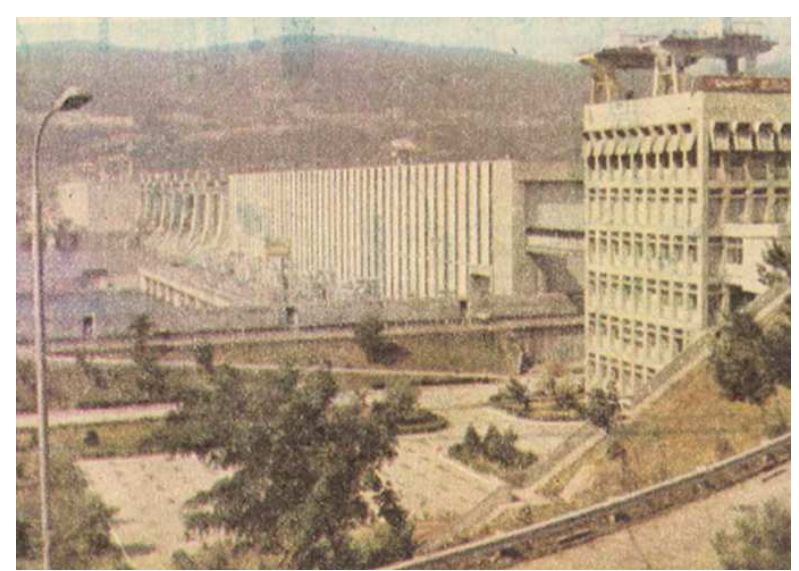

Fig. 10. Development creates new places and proud belonging: "Iron Gates I Hydropower Plant" (source: Giurcăneanu, Muşat and Ghica, 1986, p. 112).

New places appeared as a result of socialist production of large-scale constructions for housing, industry, and commercial consumption (i.e. hotels, restaurants). At the chapter on rivers, the Danube is represented at Giurgiu (Fig. 11).

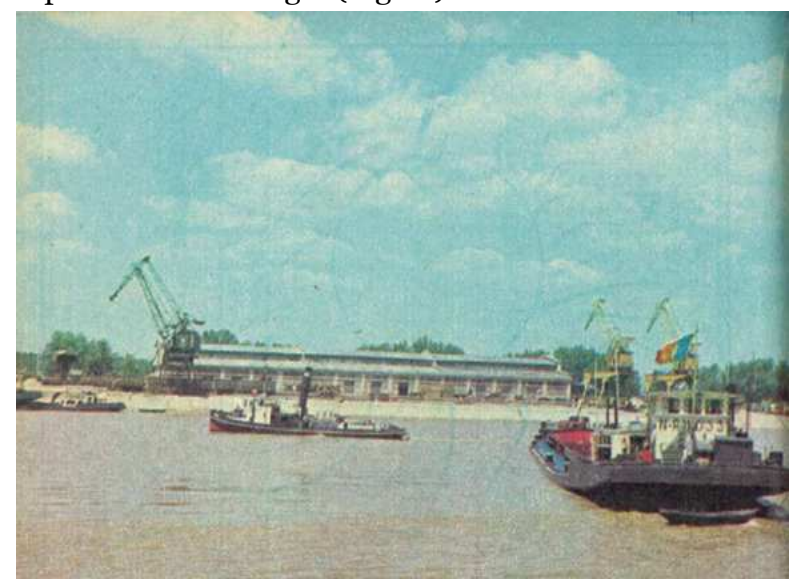

Fig. 11. Massive redevelopment of Giurgiu: "The Danube at Giurgiu" (source: Giurcăneanu, Muşat and Ghica, 1986, p. 64).

The industrial activity is provided with a representation of Galaţi (Fig. 12).

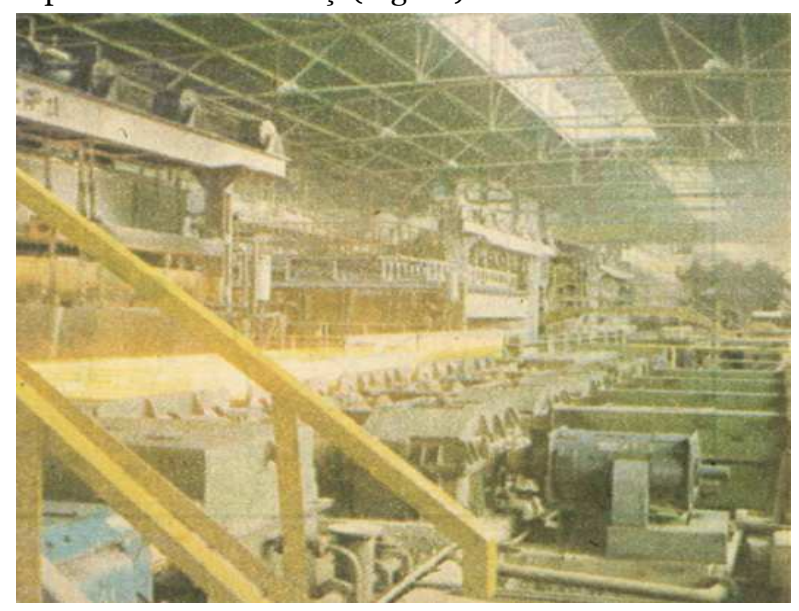

Fig. 12. Massive redevelopment of Galaţi: "View from the Steel and Iron Factories, a workshop - Galaţi" (source: Giurcăneanu, Muşat and Ghica, 1986, p. 115).
An image referring to the development of transports in Romania is that with the new bridge over the Danube, with two lanes of road, railway traffic, as well as space for pedestrians, connecting Romania to Bulgaria (Fig. 13).

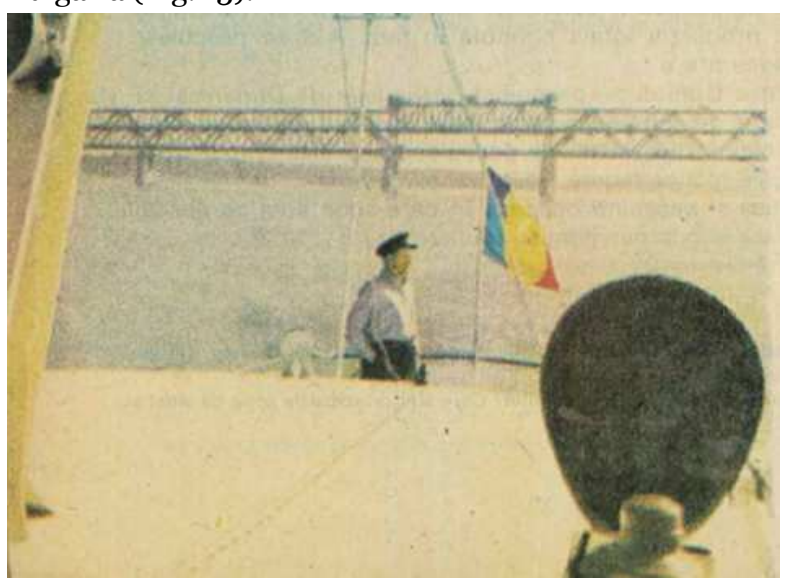

Fig. 13. Transport and cross-border cooperation between socialist countries: "The Friendship Bridge at GiurgiuRuse - with railway and road" (source: Giurcăneanu, Muşat and Ghica, 1986, p. 160).

Giurgiu-Ruse Bridge (named by the Soviets the Friendship Bridge, but after the fall of communism, it has been called the Danube Bridge), is a steel bridge, over $2 \mathrm{~km}$ long, built over the Danube between 1952 and 1954 (opened on the 20 $0^{\text {th }}$ of June 1954) (Ghinea, 2002, p. 610). For this, the communist regime was supported by the U.S.S.R., this being the first bridge over the Danube that connects Romania to Bulgaria. The central section is mobile and can be raised for big ships to pass. School textbooks are potent media vehicles of the visual hegemonic discourse on power and territory. In the case of the Danubian settlements, borders are represented through the good cooperation relations between Romania and two neighbouring countries: Yugoslavia (The Iron Gates I project, see Fig. 2) and Bulgaria (the Friendship Bridge, see Fig. 13).

\subsubsection{Analysis of the photographs in the $12^{\text {th }}$ grade Geography of Romania school textbook, the 1981 edition}

There are four images presenting new industrial architecture and two are the ones for the Iron Gates and Galaţi. The industrial activity in the study area is represented by the production of electrical energy at Iron Gates I Hydropower Plant (Fig. 14) and the ferrous metallurgy in Galaţi (Fig. 15). Iron Gates I was a model of industrial architecture and achievement, a landmark of "Ceauşescu epoch". Large scale from scratch constructions showed the political and economic potency of the regime. Representations of large-scale construction projects point out to the spatial experiences provided to the Romanians: Iron Gates I, the Friendship Bridge, new housing neighbourhoods, and industrial sites. 


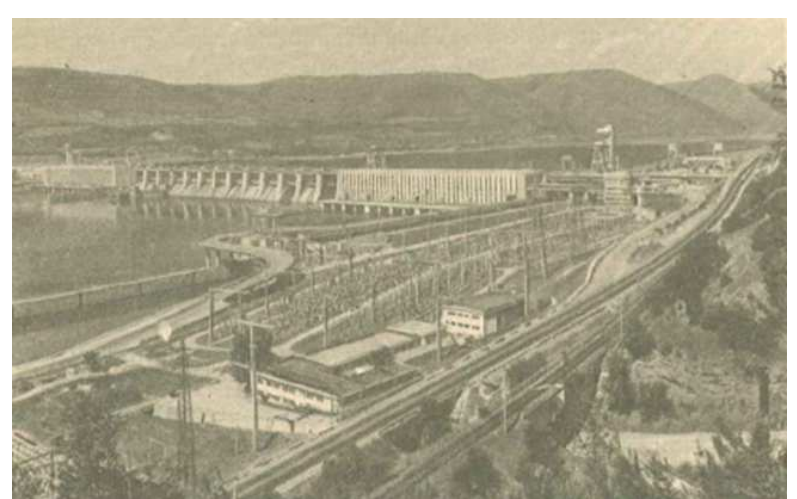

Fig. 14. Iconic and popular expressions of development: "Iron Gates Hydropower Plant" (source: Tufescu, Giurcăneanu and Mierlă, 1981, p. 72).

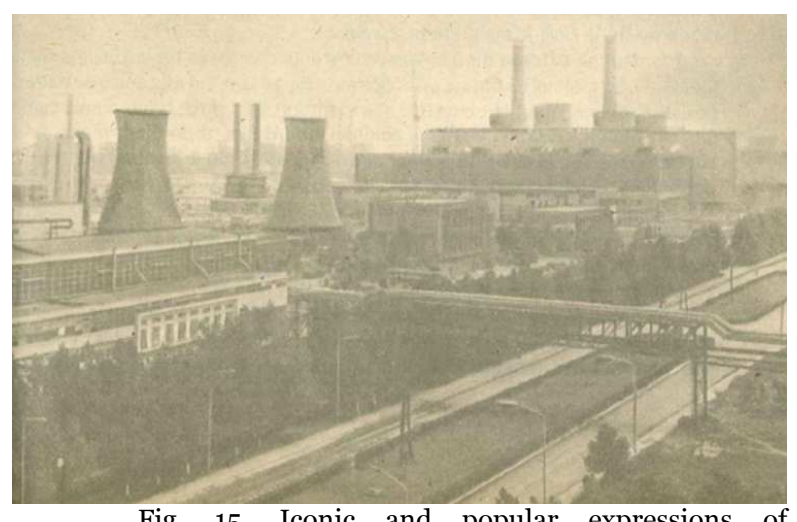
development: "Steel and Iron Factories in Galaţi" (source: Tufescu, Giurcăneanu and Mierlă, 1981, p. 77).

Besides images illustrating the Danube and activities of the Danubian settlements, in the $4^{\text {th }}$ grade textbooks, authors included exercises based on drawings, where students could recognise some of the iconic achievements of socialist Romania, featuring the construction sector and the uses of rivers, presented in the respective textbooks either through text or photographs: blocks of flats, industrial infrastructure, bridges, dams, irrigations systems, and navigable canals (Fig. 16).

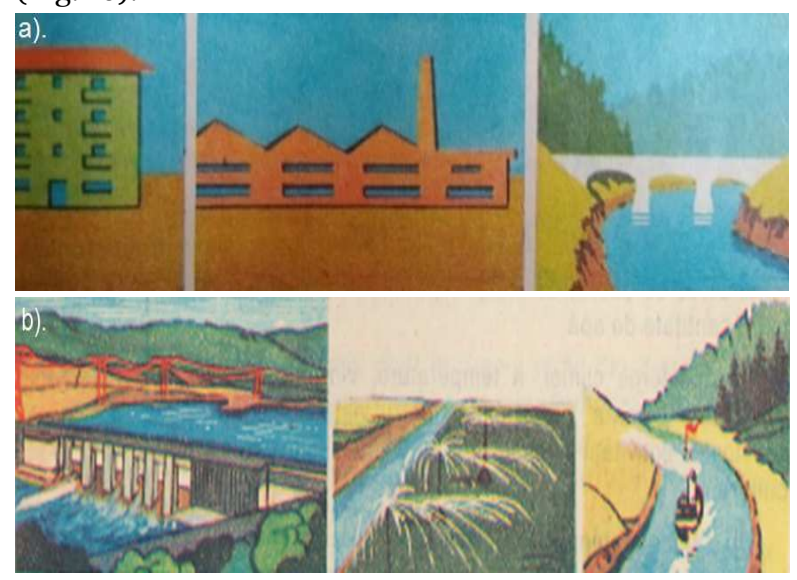

Fig. 16. Development markers of socialist Romania: a). "What materials were used for these constructions?"; b). "Look at the images and describe how people use the water of rivers" (source: Iancu, Motrescu and Negulescu, 1985, p. 71; Iancu, Motrescu and Florescu, 1989, p. 46).

\subsubsection{Some concluding insights into the analysed photographs}

Audiences are different and so are the invited ways of seeing. However, especially in textbooks, seeing is equated with knowing, because seeing the objects and landscapes represented in those photographs means learning about Romania or getting to know it through this mediated or constructed visual experience provided by the school textbook. In the analysed school textbooks, scientific authority is legitimated by statistical claims and illustrated with snapshots from reality. Those included in school textbooks claimed to be accurate and objective. Thus, scientific knowledge is constructed through images.

This discoursive visuality is part of the hegemonic political discourse in socialist Romania. Discourse is a manifestation of power and "power is everywhere, since discourse too is everywhere" (Rose, 2014, p. 192). It should be noted that although omnipresent and omnipotent, Romania was not simply a product of repressive acts, but Romanians had their own agency in contributing to this discourse formation and this is visible in schools. In the word-text of these school textbooks, Romanians are represented as a great, united, and hopeful community of working individuals, loving their homeland and their people, and trusting the Party. School is a socially powerful institution claiming to possess and transmit scientific truth and valid knowledge. Considering that access to truth and knowledge was possible through the educational system, schools were under high ideological pressure and had to collaborate with the political regime in the creation of knowledge. Thus, "the construction of claims to truth lies at the heart of the intersection of power/knowledge" (Rose, 2014, p. 193).

The school makes very strong claims about the veracity of its accounts, both scientifically and ideologically, as school textbooks were approved by the Ministry of Education and of the Education System [RO, Ministerul Educaţiei şi Învăţământului]. Thus, they were not free from workings of power and reproduced political subjectivities. Geography of Romania school textbooks are hosting powerful discourses on the territorial identities of Romania, claiming the presented knowledge to be true and thus they were very strong in producing social effects. Because in these textbook images, representations were given a truth status, besides the ideological one, their social effects were more powerful. Finally, textbooks delivered a regime of truth that teachers and students adhered to in order to achieve their aims at their job and in learning.

This institutional location (in schools) of the visual discourse makes it more dominant and influential than others due to its social authority. Therefore, the statements made in school textbooks are 
endowed with both scientific and political authority. The truth regime of the school assumes representational truth and scientific rationality, thus supporting the ideological discourse in school textbooks. Textbooks had the function of informing and realizing political education. In this way, the powerful used the school system and the apparent veracity of photographs to make their ideological discourse substantial.

Summing up, knowledge is discoursive and presented in visual form in a series of products used in schools, whose primary goal is that of educating the students. The relationship between school textbooks and ideology is quite transparent, in the contents of Geography of Romania school textbooks and methodics (i.e. didactics) of geography, which is not so obvious at a first reading of picture postcards. Therefore, in the next part, we present the results of our research on the production of picture postcards in Romania, from its beginning to the end of the 1980 s, and then we aim to prove that the key messages of textbooks related to picture postcards and were also reflected by these.

\subsection{Contextualising the image. Picture postcards in Romania}

In Romania, the first postcards were published at the end of the $19^{\text {th }}$ century when it was approved "The Law on Postcards", through the Decree no. 789 of the $31^{\text {st }}$ of March 1873 , which introduced in the service of postal communication a new object named postal card (Ceucă, 2015). The same year, the first postal cards are published in the U.S.A., France, Germany, Spain, and Serbia (Alexandrescu, 2013).

The first illustrated Romanian postcard was manufactured (but not circulated), being conceived and realised by the poet $\mathrm{Al}$. Macedonski, in 1888 (Alexandrescu, 2013). Three years later, it is circulated the first picture postcard of Timişoara municipium, which represents the central pavilion of the Industrial and Agricultural Exhibition, one of the biggest events in the field during that period, in Europe (Mochnács, 2015). Later, on the $29^{\text {th }}$ of August 1894, the first official series production of Romanian postcards was published. This was sold in Bucharest, at the opening of the Romanian Co-operators' Exhibition, when also the first official philatelic exhibition took place (Alexandrescu, 2013).

In 1895, Carol Müller's bookstore in Bucharest, sells picture postcards named "Souvenir of Bucharest" and "Souvenir of Sinaia", considered by the Romanian specialists as the first set of lithographic illustrated postcards in Bucharest (Alexandrescu, 2013). In 1938, Petru Murea, a postal office employee, published the history of the Romanian postal stamps, elaborating a special chapter for postcards with a dedicated part for answers. These are "composed by two united postcards which are sold together" (Murea, 1938, p. 325, cited in Ceucă, 2015, p. 655).

Because postcards were the easiest communication means during this period at the international level, their production registered a climax at the end of the $19^{\text {th }}$ century and at the beginning of the $2 \mathrm{O}^{\text {th }}$ century. Beginning with 1920 , production began its decline until 1950, when it came back in force, but with lower amplitude than it its glory period. At the national level, during the communist period, the production of postcards was used as a propaganda tool to advertise the economic, cultural, and technical achievements of the policies initiated and implemented by the Romanian Communist Party.

Thus, most representations in picture postcards highlighted the changes registered by the urban area in relation with socialist development policies aiming to modernise towns and cities (civic centres, universal stores, hotels, factories, Syndicate Houses of Culture, and mass-housing neighbourhoods). Displaying the city means foregrounding socialist development. The effect is that of advertising (in representations of the present) and the evocative (in those of the past) (Ilovan, 2020d).

In addition, a frequent theme in picture postcards representations was the touristic advertising of the national territory, theme common also in other socialist countries (Ştefan, 2017). Beginning with the 1960s, the communist government of Romania proposed the development of international tourism, which took place through a diplomatic opening towards capitalist countries, such as France, West Germany, and the U.S.A. (Ştefan, 2017). Later, the socialist government gave up this politics, and promoted the tourism activity only at the national level as a socialist identity for the working class. At the same time, the regime adopted a more pragmatic attitude that foregrounded the economic dimension of tourism (Ştefan, 2017).

During the communist period, the production of postcards was favoured by the fact that they were a communication means, especially due to their low price and because other communication means among Romanians were limited (reduced number of people having telephone at home and thus preferring to use postcards) (Ilovan and Maroşi, 2018, pp. 137-138). The radio, the $\mathrm{TV}$, the written mass-media offered limited information. If initially the programmes of the public television (the only available one) were varied and attractive daily, starting with 1985 , due to ideological reasons, these were limited to only two hours a day (from 8 to 10 p.m.), dedicated mainly to the personality cult of President Nicolae Ceauşescu and his wife (Silivestru, 2018). Cutting down the programme of the National Television was justified by the fact that the working people should rest and be able to work. The Romanian radio and television had to contribute 
Oana-Ramona ILOVAN, Florentina-Cristina MERCIU

Journal of Settlements and Spatial Planning, Special Issue, no. 7 (2021) 15-50

Territorial Identities and Heritage. Discourses and Practices

through its entire activity to the internal and external policies of the Party and of the Romanian state, to inform the working people about the Party's decision and contribute to the people's socialist education, enlarging their political-ideological and cultural horizon.

In 1985 , the state shut down radio broadcasters to save electricity. In fact, this was a strategy to support Romanian nationalism by interfering with those broadcasting in Hungarian and German. The influence of the political factor was very high on information broadcasted through television and radio, or in the written mass media, regulations being established through laws and Party documents. The Law of Journalism adopted in 1974 stipulated that "the press activates under the leadership of the Romanian Communist Party, the leading political force of the whole society in the Socialist Republic of Romania" (Păsăilă, 2004, p. 258).

Thus, the role of postcards as a tool of communist propaganda was justified. We underline a special situation for using postcards as the only communication means with their families of those who were forced to work for building the Danube-Black Sea Canal (Lefter, 2017). For constructing the canal, the state used forced labour and those working there had no other means of communicating with their families so that they were not given the opportunity to send information about the very difficult working conditions.

There are two sub-stages in the production of postcards during the communist period: (1) the Popular Republic of Romania, when postcards were black and white, but had an exceptional photographic quality, and (2) the period of the Socialist Republic of Romania, when the first colour picture postcards appeared, which, starting with 1963 , became permanent, but they were less artistic and had a lower quality compared to the previous ones, because they were edited at low costs (Both, 2017). 1973 marked the anniversary of a century since the first Romanian postcard was published. This moment was celebrated by editing a catalogue of postcards (Ceucă, 2015).

How images were produced may contribute to the construction of meaning, to the "reality effect" or apparent truthfulness in case of photographic representations, for instance, in comparison to other images (e.g. drawings, paintings). Photographs are expected to provide us with glimpses into the truth of a certain moment.

In the case of the reception of information in textbooks, the rules are policed by teachers. The authority of the school was used to persuade that such representations of reality were truthful. This was true also when using picture postcards during lessons. However, there is no assumption that the implementation of rules or of educating a certain way of seeing are entirely successful activities.

\subsection{Most frequent representations in picture postcards for the Romanian Danubian settlements}

The ways in which picture postcards are displaying icons, narratives or short discourses on territorial identities are two: single images and collages. We include a synthesis about the key representations for each Danubian settlement considered in this study. We use the syntagm "old postcards" for those published before the socialist period.

Baziaş is represted only in old postcards, and the most frequently illustrated place is the former railway station. The settlement is known due to two elements: one is geographically important (the place where the Danube enters the territory of Romania) and the other one is economically significant (it represented the terminus point of the first railway Baziaş-Oraviţa, which was continued by the segment Oraviţa-Anina, known under the name of "the coal line" (the line was for the transport of coal exploited at Anina; from Baziaş harbour, the coal was transported on the Danube upstream to Austria). The construction of the railway began in 1847 and was finished in 1854. The sector Oraviţa-Baziaş had a $62.5 \mathrm{~km}$ total length. On the 1 st of November 1856, the passenger traffic was opened (Lăcriţeanu and Popescu, 2007). This railway continued on the territory of Yugoslavia, on the route Baziaş-Bela Crvka (Biserica Albă, today in Serbia)-Jasenovo (Serbia)-Iam (Rusnac, 2011). During the communist period, the railway was closed according to Josip Broz Tito's decision (except for the segment Vârşeţ-Biserica Albă) to terminate its functioning in Yugoslavia (the present territory of Serbia), and the economy of Baziaş declined. Not used since 1950, the monumental building of Baziaş railway station was demolished in 1960 , when it was considered that the respective place would be flooded by a raise in the level of the Danube, once the dam of the Iron Gates was built (Rusnac, 2011). This explains the lack of representing Baziaş in picture postcards during the socialist period.

Moldova Nouă developed much during the socialist period, when it was declared a town (1956), due to its industrial profile, starting to exploite copper in 1957, and in 1965 they set up a factory for the primary processing of this ore. The town hosted the second largest copper exploitation area of Romania (Manea, 2003). For Moldova Nouă, there are few representations. During communism there were two circulated representations: one from the 1960 s, with the House of Culture, and another one of 1975, where the viewer sees the new settlement and the Danube, titled: "Moldova Nouă. On the bank of the Danube", both testifying for the modernisation of the town.

For Orşova, there are representations of old postcards edited in German and Romanian; the most frequent represented elements are Cazanele Dunării 
(part of the Danube Defile), and panoramic images of the town with a view towards the Danube. We noticed a continuity of representations of the harbour in postcards during socialism. We found collages inviting visitors to Orşova ("Visit Orşova") or mentioning "Greetings from Orşova", and "Greetings from New Orşova". The centre of the new city is represented, with new blocks of flats along the Danube and the harbour. The modern Hotel "Dierna" (name of a Dacian-Roman settlement, which became a municipium under the rule of the Roman Emperor Septimiu Sever, 193-211), then a view towards the gulf of Cerna, the river station, the touristic basis for the youth (Saint Ana Monastery), esplanade (large street in the park, also blocks of flats), the bank of the Danube, and the shipyard. A statue with Poseidon, the Roman God, with the trident, signifies the properties of water (liquidity, fertility, drinkability), in "General Dragalina" Park (named after the Romanian general who fought against German troops, in World War I).

Isle Ada-Kaleh, situated in the riverbed of the Danube, $1 \mathrm{~km}$ downstream of Orşova (Ghinea, 2002, p. 16), appears frequently represented beginning with the 19th century until the year 1970. In some postcards, there are represented archeological (the ruins of the citadel Ada Kaleh) and religious (mosque) relevant elements. In 1971, the isle was covered by the waters of the Iron Gates I Lake (Ghinea, 2002, p. 550).

For Drobeta Turnu Severin, we identified postcards from the before the Great War and the socialist period, where the most frequently represented elements were: the harbour, the archaeological traces of the Roman period, and ruins with heritage value. Ruins of the Roman castrum Drobeta appear also in collages. Other represented ruins are those of the Trajan's bridge (i.e. the foot of the bridge), the ruins of the Severin fortress, insula Simian - the ruins of Ada Kaleh. Frequently represented are the monuments dedicated to the heroes.

Single standing or in collages are represented pieces of historical heritage and symbols of economic activities, and of the political presence in the area: the statue of Emperor Trajan, the north-eastern tower of Severin Fortress, the Obelisk of the Romanian Heroes from World War I, the bust of Apollodor of Damascus, the Museum of the Iron Gates Region, and the Museum of the Hydropower Plant Iron Gates I. During socialism, frequent images are those of Hotel "Parc", Hotel "Trajan", Commercial Complex "Modern", also called Kiseleff (Russian general who contributed to the administrative reorganization of the Romanian Principalities, supporting their Union), the building of the Prefecture, the House of the Youth, the Theatre, the Monument of the Patriotic Guards, and the postal office.

For Calafat, there is continuity in representing the Danube in old picture postcards and in communism. Before socialism, an old postcard presents the battle of Calafat, underlining the historical events within the town. The most frequent representations during socialism are of elements associated to the Danube, such as constructions or arrangements for leisure activities (the embankment, the park, an alley on the riverfront), or to the Independence War (1877-1878) (e.g. the brigade "Mircea" in Calafat, the monument of the heroes who fought in that war). Other representations are for iconic buildings of the communist power (the Popular Council, the House of Culture) and with a religious function (the cathedral).

For Corabia, we found few picture postcards. In the old ones, there are represented buildings in the central area of the town. During socialism, frequently represented are the ruins of the Dacian settlement Sucidava, 4-5 km from the city. There is continuity in representing the harbour in the socialist period and before. Often represented are the Roman fountain, the Popular Council, the Danube riverfront, the Monument of Independence, the Monument of Heroes, Restaurant "Faleza", Commercial Store "Supercoop-Corabia". Some of those published in the 1980 os were circulated in the 1990s (this could be identified through the date on their back). Thus, these representations are present also physically in after-1989 Romania.

For Turnu Măgurele, there is continuity in the representation of the town cathedral. In the old postcards, there are represented also other symbol elements for the town history: the central area of the town, the customs, and the police building. During communism, there are represented buildings realised during the respective period: "Gh. Gheoghiu-Dej" cinema and the boulevard, blocks of flats, the Popular Council, the universal store, the postal office building, and a church. The harbour is represented in postcards that were published only before communism.

For Zimnicea, we identified several old postcards where the harbour is represented. In those from socialism, there are representations of the Danube (among which, one in the late 1960s where "meleaguri dunărene" [Danubian places] is written by the sender on its back), or of buildings from this period (e.g. the Industrial High School, with a red Dacia partially photographed in the foreground). During the Independence War (1877-1878), Zimnicea was an important place for crossing the Danube by the Romanian and Russian armies. At the end of the 19th century and the beginning of the $20^{\text {th }}$, this town developed slowly, and after 1968, it underwent swift economic and urbanistic changes. Almost destroyed (over $80 \%$ ) by the earthquake (7.1 magnitude on Richter scale) on the $4^{\text {th }}$ of March 1977, the town was reconstructed by 1980 (Ghinea, 2002, p. 1448).

Giurgiu is represented in many postcards. We identified the continuity in representing the Clock Tower, which has been also a firemen's tower. In some 
postcards, only the tower is represented, and in other, this is only in the background when the focus is on the central area (both in postcards from before and during communism). In postcards before socialism, the focus is also on the old city streets (Prince Nicolae Street, Carol I Square, Carol I Street - names of the Romanian royalty -, Railway Station Street, Harbour Street, etc.). These streets are no longer represented during the socialist period.

There is continuity in representing the harbour, without any focus on its economic function, like in the case of Galaţi; in old postcards, the harbour is represented together with vessels, some in St. Gheorghe Canal, connected to this harbour. During communism, many collages represented only the harbour, or the harbour and some buildings in the city, usually those realised during the respective period: the House of Culture (1969), the CEC building [House for Economies and Agreements], the county museum, and those in the civic centre. During this period, there are many representations of the river harbour station. It appears also with the inscription: Traiască Partidul Comunist Român [Long Live the Romanian Communist Party]. The Friendship Bridge appears often, sometimes with ships in the same image. One may conclude that the Danube and related activities (i.e. shipyard) are very well represented, and these are repeated over decades.

For Olteniţa, there is continuity in representing the harbour, the shipyard, and the Monument of the Heroes. During socialism, new introduced elements are the Popular Council and industrial objectives. Likewise, for Călăraşi, where appear representations of iconic buildings raised during the socialist period: the restaurant in the embankment area, the Popular Council, and the silos. For Cernavodă, Carol I Bridge (the bridge railway), created according to the plans of engineer Anghel Saligny, is represented in many picture postcards (published during and before socialism). In addition, on the 21st of November 1987, a new ensemble of railway and road bridges between Feteşti and Cernavodă is open (Ghinea, 2002, p. 571). In socialism, it is represented the Cernavodă sector of the Danube-Black Sea Canal.

For Feteşti, during socialism, there are representations of buildings raised in the civic centre (e.g. new central commercial complex). On postcards, appears the Monument of the Romanian Air Force, as in Feteşti there was a brigade. The few postcards are dominated by representations during socialism, especially as it became a town in 1950 and it was a railway station node. It is relevant to underline that here there is the railway bridge over Borcea branch of the Danube (920 m long) - sector of the complex of railway bridges built between 1890 and 1895 by engineer Anghel Saligny (Ghinea, 2002, pp. 407-408).

For Hârşova, we identified old picture postcards, where it is represented that part of the town 32 that has a view towards the Danube or the cliffs characteristic of this sector.

For Măcin, there are just a few representations during communism: elements of local culture characteristic of the Turkish minority (the mosque appears frequently) and the socialist central area (e.g. image with two Dacia cars and the civic centre).

For Brăila, there is continuity in representing the harbour and the water tower. Other frequent representations are those including Hotel "Trajan”, V.I. Lenin Square - in front of it, the shipyard, the statue of Emperor Trajan, the river station, the riverfront, the polyvalent hall.

For Galaţi, we notice the continuity in representing the harbour (with more representations than for Brăila). Old postcards include representations of the floods that impacted the city in 1897. Socialist ones include representations of industrial units (e.g. the Iron and Steel Factories), ships on the Danube, the River Station, statues, individual heritage buildings, images with districts of blocks of flats, the city centre, Complex Hotel and Restaurant "Dunărea" [the Danube], Hotel "Libertatea" [Freedom], the House of Culture, Hotel "Galaţi", Hotel "Turist", the riverfront, and in general a variety of new buildings.

Nothing relevant for the socialist period appears in postcards for Baziaş, Bechet, and Hârşova. From the representations of the Iron Gates and the Danube, we see that heritage is lost and replaced with other identities (in the first case), or there is continuity in representations, especially related to economic activities. As a borderland area, during communism, mostly circulation and electricity production isssues were solved through cross-border cooperation. In addition, the achievements of the communist Golden Age are the new represented elements.

From these representations, the viewer sees the southern border of Romania displayed as natural (the Danube) and political (through economic cooperation with Yugoslavia and Bulgaria). The Independence War related representations point out that this event is relevant for the territorial identities of these Danubian settlements. The Dacian and Roman past are a leit motif, while socialist development is usually related to or dominated by the Danube.

\subsection{Picture postcards collages and territorial identity stories of the Danubian settlements}

Orşova is situated on the shore of the Iron Gates I accumulation lake on the Danube, in the area where the Cerna flows into the Danube. The old settlement registers several significant moments during its development: between 1772 and 1870, Orşova is part of the Military Border District of the Austrian Empire, in 1910, the shipyard is opened, and after the Union of Banat with Romania, it is declared a town (in 1923). 
Between 1966 and 1974, the town is moved due to the building of the Iron Gates hydroenergetic and navigation system (Ghinea, 2002, p. 926). The idea of sacrifice for the betterment of the Romanian society is reminded through the presence of the Museum of the Iron Gates Region. The creation of the Iron Gates I hydroenergetic and navigation complex changed the lives of those in Orşova and Ada Kaleh. That is why Orşova is represented through its political administrative building, in a collage, integrated into the greater narrative of development for Mehedinţi County (Fig. 17).

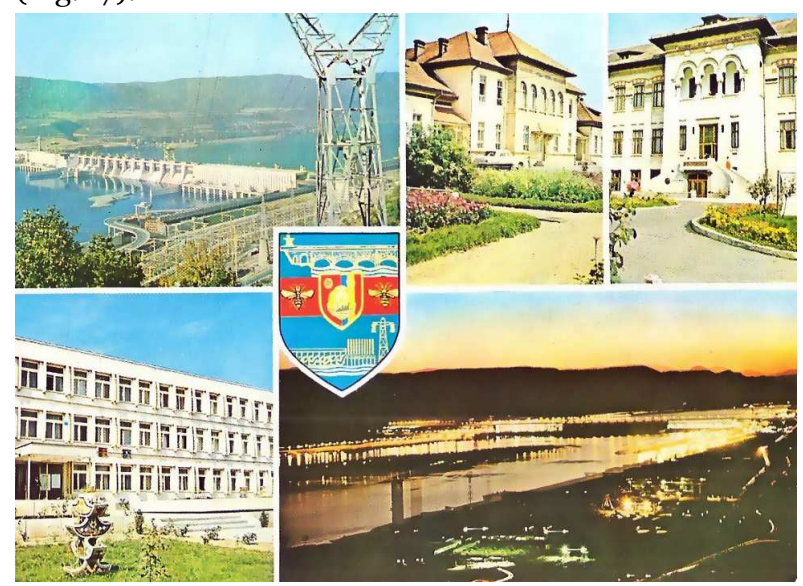

Fig. 17. History and becoming in Mehedinți County: Iron Gates I Hydroelectric Power Plant (functioning at maximum capacity starting with 1972), House of Culture in Strehaia (built between 1950 and 1956), Museum of the Iron Gates Region (in Drobeta Turnu Severin, set up in 1912, fully developed after 1972), Popular Council Orşova (of the new town), Iron Gates I hydroenergetic and navigation system (built between 1964 and 1971), the coat of arms for Mehedinţi County (1975, published by OSETCM).

Most of these photographs show daylight, but in the case of the last photograph of this collage, the objective is pictured by night in order to show how welllit it is; it is a "fortress of light" - producing electricity. Representations of authority in the form of politicaladministrative buildings are often (Fig. 17, 19 and 23).

Iron Gates I Hydroelectric Power Plant is the biggest one on the Danube (Ghinea, 2002, p. 549) and it has an installed power of 1,080 MW. Present at Turnu Severin on the $7^{\text {th }}$ of September 1964, Gheorghe Gheorghiu-Dej and Iosip Broz Tito laid the foundation stone, after discussions had started in 1955 at the initiative of the Romanian state. The Iron Gates is the inferior sector of the Danube Defile, between the settlements Vârciorova and Gura Văii, $9 \mathrm{~km}$ long (Ghinea, 2002, p. 990). The Iron Gates I Power Plant is placed $15 \mathrm{~km}$ upstream the city of Drobeta Turnu Severin. Building the dam and creating the accumulation lake enabled navigation (before that there were frequent shipwrecks, ships would sail only during daytime and crossing the defile took 120 hours) (Ghinea, 2002, p. 990). The Iron Gates I project was realised by Romania in collaboration with Yugoslavia (September 1964 - September 1971). The Iron Gates I system is one of the biggest in Europe. The dam enabled the raising of the water level with approximately $33 \mathrm{~m}$ over the average one and the creation of the Iron Gates I accumulation lake. The two hydroelectric power plants, with an installed power of over 11 million KWh yearly, started to function with their first water-turbines in 1971. The hydroelectric power plant on the Romanian bank started to function at maximum capacity on the 16th of May 1972 (Ghinea, 2002, pp. 990-991), when it was held also its opening. This hydroenergetic system is a symbol of the Romanian energy sector and of crossborder cooperation. It was also a symbol of the economic power of Romania during that period. The Museum of the Iron Gates I Hydroelectric Power Plant opened in 1976.

This hydroenergetic giant determined major changes in the physical and human geography of the area: the Isle Ada Kaleh disappeared under the accumulation lake, the tributaries of the Danube raised their river mouths, the old town of Orşova disappeared under the waters of the same lake, a new town was built on the terraces of Danube and on the slopes of the Almăj Mountains, and new transport routes were built (Ghinea, 2002, pp. 990-991).

The Museum of the Iron Gates Region is a regional museum in Drobeta Turnu Severin. Initially a history museum of "Trajan" High School (1912), in 1926, it is moved to the new building raised nearby the Roman castrum Drobeta. After 1945, the museum gains more importance and enlarges its research area, being named the Museum of the Iron Gates Region. Starting with 1972, it had two sections: history and sciences of nature, and later the ethnography and plastic art sections (Ghinea, 2002, p. 550).

In this collage, there are two representations of development, the political factor, culture (a building in Strehaia, raised during the socialist regime) and the museum as holder of heritage and of the history of development in the respective area (from ancient times). The identity of Mehedinţi County is constructed based on the Danube and related representations, as reflected also in its coat of arms, hosting the following meanings: the golden bridge evokes the construction raised here, over the Danube, in Antiquity, by Apollodorus of Damascus; the silver construction represents the Iron Gates I Hydroelectric Power Plant, pointing out the modern achievements for electricity production; the bee is from the old coat of arms of the county, dating to 1715 , reminding of both an old craft and of the locals' industriousness (Guvernul României, $2007 \mathrm{~b}$ ). Postcards only with the coat of arms of the counties were available also single standing.

Drobeta Turnu Severin is the county residence for Mehedinţi. During the Roman Antiquity, Drobeta became the first urban centre of the region and the third in the province of Dacia, after Sarmizegetusa and Apullum. The Austrians were again present in the area, 
in 1829, building the harbour of the town, and in 1850 , the shipyard necessary for repairing ships damaged by the difficult crossing of the Iron Gates Defile.

Until the $15^{\text {th }}$ of May 1972, the municipium was named Turnu Severin. Drobeta was added to the city's name to remind of the antique Dacian settlement Drobeta, mentioned by Ptolemy, who wrote that during the first Dacian-Roman War (101-102 A.D.), the Roman Emperor Trajan had set up in Drobeta a big and important military centre (which had stayed under Roman administration until the 3rd century A.D.) (Ghinea, 2002, p. 550). Underlining the national identity based on Tracian-Dacian precedence was a common trope in the communist ideology of the 1970s and 1980s. One day after Nicolae Ceauşescu and Iosip Broz Tito participated at the opening ceremony of the Iron Gates I Hydroenergetic System, I, on the 16th of May 1972, the name of the town becomes Drobeta Turnu Severin. This sequence of events underlines the political attention paid to the legitimation of the political regime both through history, which authenticates the present, and through contemporary economic achievements.

A variety of symbols were included in collages for this city. For instance, the House of Culture and universal commercial stores, such as Commercial Store "Modern" (cf. Fig. 18), are elements in a pattern of representation focusing on cultural and economic continuity and progress in the Romanian socialist society (Ilovan, 2020d). Collages aimed to showcase development and architectural models for the urban area, and often the "search for legitimation is tied to the production of bold and highly visible urban forms and infrastructures, particularly within cities" (McClelland, 2020, p. 164). Political ideology in socialist Romania was materialised at the city scale and was particularly salient in the form of new and monumental architecture (cf. Fig. 18, with Commercial Store "Modern", and Fig. 19, with the County Popular Council). So, what are the provided spatial experiences in these towns and cities? These relate to the Danube, to the memorialization of space and to the new way of living in the modernised city (Fig. 27).

In the second collage (Fig. 19), the general view with the Danube in the background and the water tower repeats the representation in the first collage (Fig. 18). This repetition makes the respective landscape iconic in representations. At the same time, the first image also portrays development through a large boulevard, with the postal office building (signifying communication) and the County Popular Council (the political presence). The Museum of the Iron Gates area is another iconic image that appears both in representations of the county (cf. Fig. 17) and of Drobeta Turnu Severin (Fig. 19). The museum is the image of heritage, as well as of development as it documents the evolution of the area and refers, through its name, not only to a sector of the Danube, but to the recent works for hydroenergy production and navigation. The meaning attached was the one that made buildings socialist, if not built during that period, but before (cf. Fig. 19).

In our analysis of these collages, we relied on both the historical context, historical significances, and spatial relationships, but in addition, visual axes are used in some collages in order to focus the viewer's gaze, like in this picture postcard (Fig. 19) in the upper left corner image, where the hierarchy of places highlights the Danube in the background and the political-administrative centre on the first places.

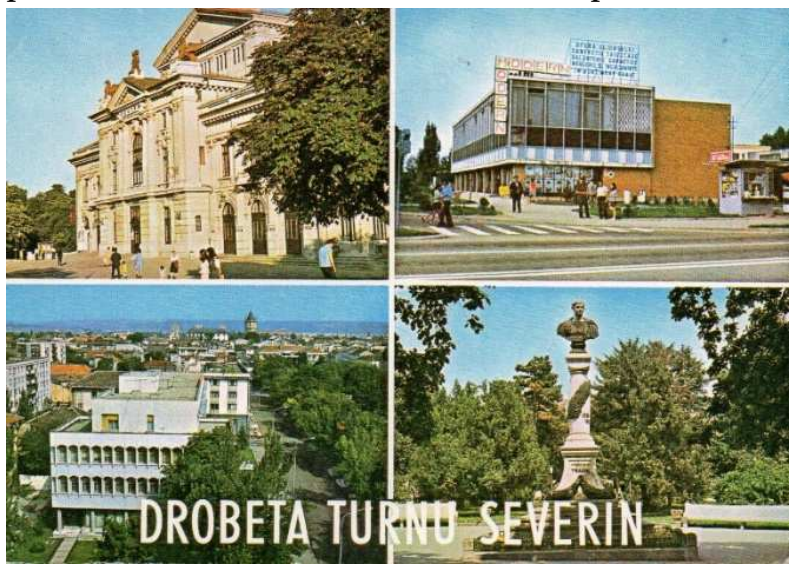

Fig. 18. The monumental city created through visual representations - Drobeta Turnu Severin: House of Culture, Commercial complex "Modern", General view (with the Danube in the background and the water tower), Bust of Emperor Trajan in the 1970 (realised in 1906 by the sculptor D. Franasssovici) (publ. in 1976, OSETCM).

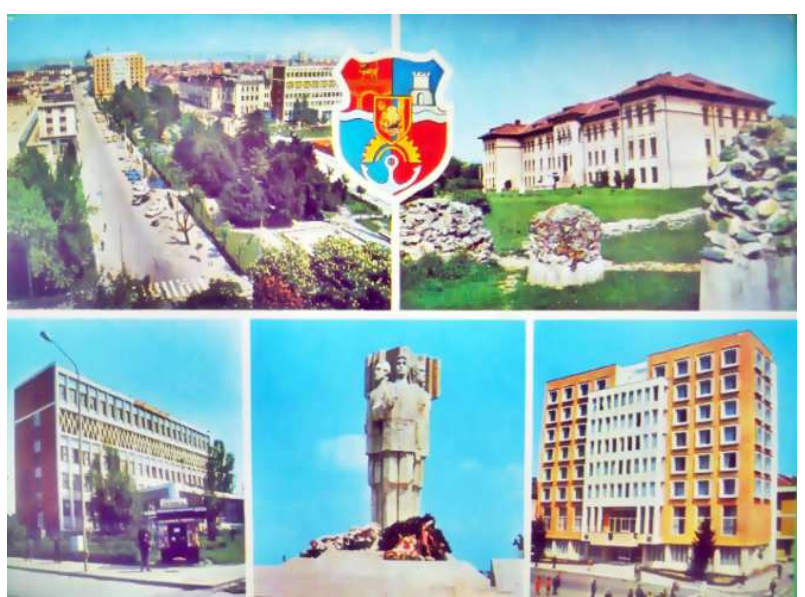

Fig. 19. The monumental city created through visual representations - Drobeta Turnu Severin: General view (the Danube in the background), Museum of the Iron Gates Region, Postal Office, Monument of the Patriotic Guards, County Popular Council in the Administrative Palace (publ. in 1977, OSETCM, photos by V. Stamate).

This position of images within a collage, relative to one another, is a relevant analytical element for decoding ideological agendas or interpreting meanings that are reinforced through the juxtaposition of collages components. For instance, earlier symbolic structures are rendered less significant when placed in a 
secondary position towards other newer elements of the represented city-scape (Fig. 19). These representations render "space as a political good" (Dellenbaugh-Losse, 2020, p. 17), translated into a national space, part of the national narrative of socialist Romania. Narrative and symbolic recontextualization through representations is a powerful strategy used by those in power to alter meanings. From this, one can deduce a ranking of places and urban symbols in picture postcards, the new one being given priority in representations. The past is invoked to give more significance to the present. History is called in the service of the socialist state, to legitimise socialist renewal based on authentic previous achievements. Thus, visual representations are a tool for constructing territorial and national identities in the hands of political actors, especially under a totalitarian regime, where alternative discourses were silenced.

The appearance of commemoration places led to a domination of space through ideological messages or a change of the initial message through recontextualising the representation. For instance, the monument of the Patriotic Guards, realised by sculptor Iulia Oniţă, in 1974, serves to represent the Communist Party and its wise decisions for defending the socialist homeland: „On the $21^{\text {st }}$ of August 1968, the Plenary of the Central Committee within the Romanian Communist Party decided to create the patriotic guards - armed and voluntary brigades of the working people in towns and villages - that would participate, together with the armed forces, at defending the People's revolutionary conquests, at ensuring its peaceful work, the independence and security of the homeland. Creating the patriotic guards increases the defence capacity of the Socialist Republic of Romania, and besides this, our country's contribution to fortifying the world socialist system, against the aggressive politics of Imperialism". It was decided by President of the State Council, Nicolae Ceauşescu (Consiliul de Stat, 1968).

The coat of arms of Drobeta Turnu Severin during the communist period includes the bridge of Apollodorus of Damascus (103-105 A.D.), the lion reminds of the old sign of the Roman legions, and, on the other hand, of the fact that Severin belonged to Oltenia. The tower evokes the Medieval borough of Severin, the mural crown with seven castellated towers signifies the fact that the settlement is a municipium and county residence. The anchor signifies that it is a harbour at the Danube. In the middle of the coat of arms, there is the flag of the Romanian Communist Party and of Romania (Guvernul României, 2007a).

The Administrative Palace is one of the representative edifices of the socialist period, besides the nearby blocks of flats and Hotel "Parc". A new urban identity is invented and a tradition of representing the urban area is established during the socialist period, as symbols of the past are connected to those of the present in an attempt to normalise the political regime through historical continuity. Both past and present are staged visually in collages in order to create an identity significant story within an urban image-building process (Fig. 18, the building of the House of Culture dating to 1912 and used for various cultural activities and meetings during socialism; the figure of Emperor Trajan evoking Romanians' origins and witnessing contemporary changes).

Corabia town was set up in 1871 , at the request of the traders in the region, when it was adopted the Law on setting up Corabia town, providing for the necessary land to build dwellings and public utilities and it established the new harbour at the Danube (The Town Hall, 2021). The basic activity remains the harbour related one and through Corabia took place the largest part of the river trade with cereals. During the communist regime, the harbour is closed. A forced industrialisation regime is imposed and it becomes a strong industrial centre (Ghinea, 2002, p. 464).

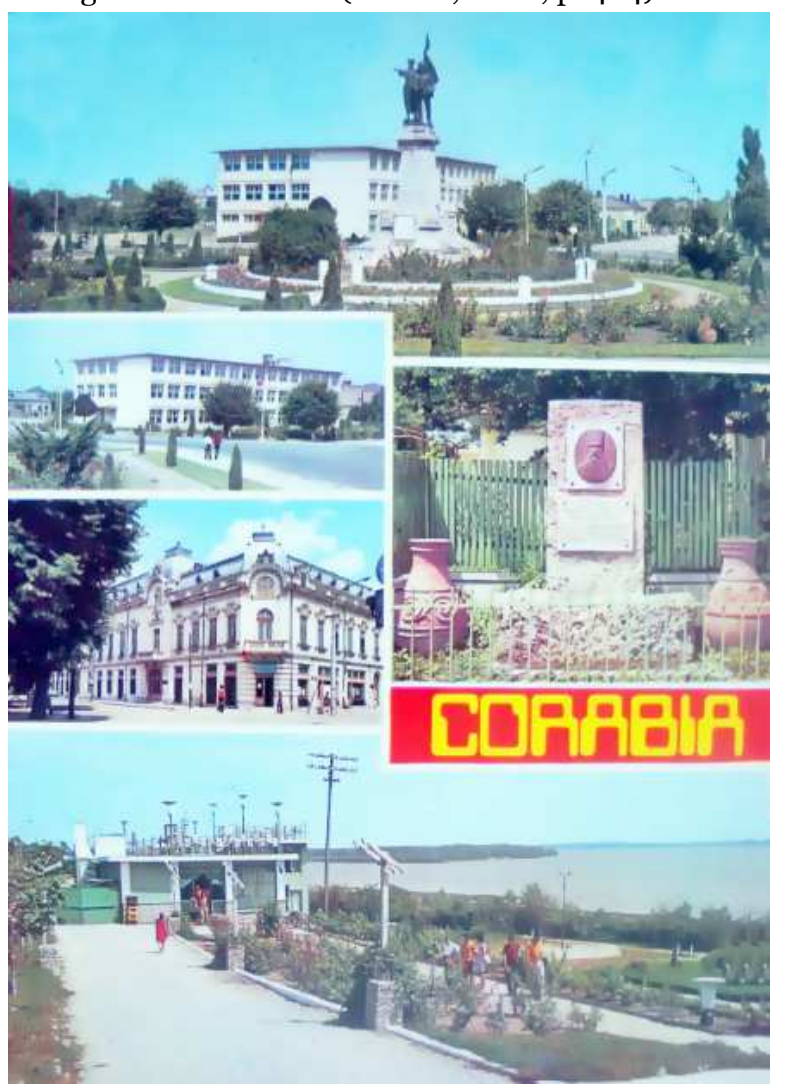

Fig. 20. Glorious past and modern present in Corabia: The Monument of Independence (built in 1922, dedicated to those who fought in the Independence War, 18771878; it dominates the civic centre of Corabia), High School of Industrial Chemistry, the House of Culture, the monument dedicated to the priest Radu Popa Şapcă (fighter for the rights of the oppressed), Restaurant "Faleza" (1975, Meridiane Publishing House).

Figure 20 shows which are the actors in the story of Corabia town: history (a monument dedicated to Romanian heroes of the Independence War, and another one dedicated to a priest-leader of the 1848 revolution), education (the economic profile of the local high school in the 1970s), culture (the House of Culture) 
and relaxation nearby the Danube (the commercial activity of the Restaurant "Faleza" [Riverfront]). They build a story - a vision of well-being in the modernized urban area, with all the facilities accessible (school, culture, relaxation) (Fig. 20).

The Monument of Independence (built in remembrance of the Romanian heroes who fought in the Russian-Turkish War of 1877-1878, which led to Romania's independence), is made of a marble plinth on which stands an allegorical sculptural group, made of bronze, which represents a young woman, flag in her arm, dressed in peasant clothes, who symbolises the genius of Romania, and who points to a heroic standing soldier the place to cross the Danube and where the Romanian army actually crossed it during the respective war, to fight the Turks. In time, the plinth was covered with marble plates that displayed the names of the heroes from Corabia, who died during the Independence War, the World War I and II. This monument is placed in the city centre, surrounded by the Town Hall, the High School of Industrial Chemistry (now "Alexandru Ioan Cuza" National Collage) and a church ("The Holy Trinity").

The educational institution is represented twice in this collage, first in the background of the above-mentioned monument and then as the main objective. On the $17^{\text {th }}$ of October 1919 , The Ministry of Education and Cults approves the functioning of a secondary school in Corabia. After the reform of the education system in 1948, it is mentioned the mixt high school with classes from the 1st to the 11th grade, which, starting from 1954, functions according to the Soviet model, from the 1st to the 1oth grade. In 1965, the school takes up the name of High School for General Culture, with classes from the 1 st to the $12^{\text {th }}$ grade. In 1974, the school is transformed into the High School for Industrial Chemistry, with classes of chemistry, mechanics, and electrotechnics (Liceul Teoretic Alexandru Ioan Cuza, Corabia, 2019).

The priest Radu Popa Șapcă (1795-1876) was a local leader during the Revolution of 1848 , which was considered the first step to Romania's national independence. He advertised revolutionary ideas to the people gathered on the field nearby the village of Islaz, on the $9^{\text {th }}$ of May 1848 (e.g. the abolishment of the peasants' servitude, of forced labour and of unjustness) (Apostolache, 2010).

Giurgiu is situated both in the plain area (the Burnaz Plain) and in the Danube's Meadow. Giurgiu Harbour was set up in the 1500-1600, initially as a freight harbour, and terminal for cereals, which were exported to the Austrian-Hungarian Empire and to the Ottoman Empire, then it was used for the export of salt (brought from Prahova area) (Duşoiu and Gacichevici, 2015). Giurgiu harbour was connected to Bucharest by railway starting with 1869 and was the first of its kind to have this direct connection (the first railway in the 36
United Principalities of Moldavia and Wallachia) (Ghinea, 2002, p. 609; Dorobanţu, 2020, p. 7). The harbour always had the function of transferring passengers who came with the tourists ships on the Danube (Fig. 21). It was a border and customs point, providing railway and road connection to Bulgaria. It had also a shipyard.

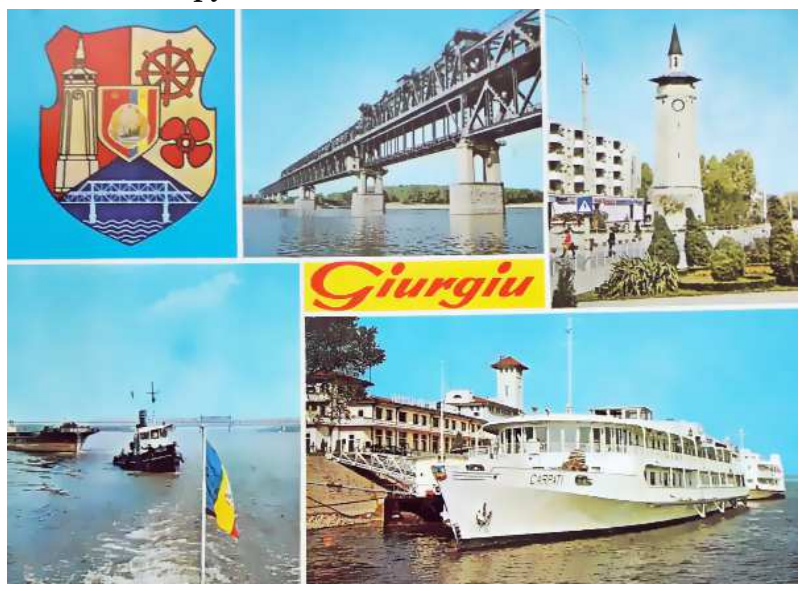

Fig. 21. Giurgiu municipium, harbour, industrial and commercial city, border crossing point: The coat of arms, Giurgiu-Ruse Friendship Bridge, a view from the city centre with the Clock Tower, the ship "Nova Carpaţi" in front of the River Station, a view of the Danube with a small ship and the flag of the Socialist Republic of Romania in the foreground (1974, publ. by OSETCM).

The Clock Tower, dating back to the 18th century, since the period of Ottoman occupation, a symbol of the city, is situated in Union Square (Fig. 21). It is $22 \mathrm{~m}$ high, built (of stone) by the Turks for military observations (rebuilt in the $19^{\text {th }}$ century, when the clock was added) (Ghinea, 2002, p. 610).

The coat of arms is a representation of the historical traditions and economic, social, cultural, and scientific realities of the municipia and counties. When representing the historical past, there were used symbols from old coats of arms or old artifacts (i.e. seals and stampers) and documents (Consiliul de Stat, 1972).

On the county coat of arms for Giurgiu, it is represented the Clock Tower, a steering wheel, a ship propeller, a portion of the Friendship Bridge (see discussion at point 4.1.3), the coat of arms for the Socialist Republic of Romania, against a background formed, on the left, by the flag of the Communist Party, and, on the right, by the flag of the country (Consiliul de Stat, 1972).

The colours of the collage are used to compose the colours of the Romanian flag: the name of Giurgiu is written in red on a yellow background and the blue Danube and the sky surrounding it. Picture postcards display a modern way of life where the Danube was represented both as a touristic resource (Fig. 21) and an economic one (Fig. 22).

This second collage representing Giurgiu city (Fig. 22) includes the Clock Tower in three images, and the Danube in other two. 


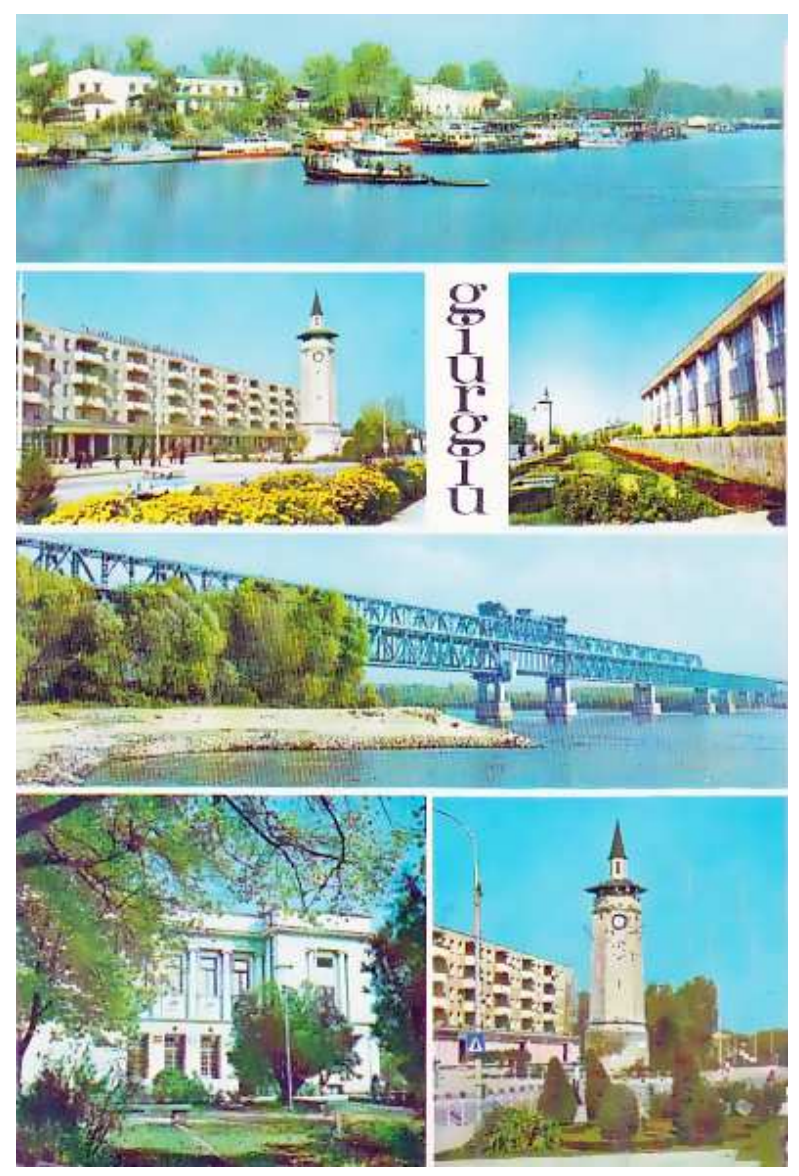

Fig. 22. Giurgiu, historical and economic accomplishments near the Danube: the commercial harbour with barges on the Danube, the city centre with the Clock Tower and the slogan "Trăiască Partidul Comunist Român" [Long Live the Romanian Communist Party] on the roof of the nearby blocks of flats (a central proof of the state production in the housing sector), the road and railway bridge Giurgiu-Ruse, the Museum "Teohari Antonescu" and again the city centre (circulated in 1979, Meridiane Publishing House).

A new image is with a museum, bearing the name of a Romanian archaeologist, historian, and professor, who lived between 1866 and 1910. Set up in 1934, "Teohari Antonescu" County Museum functions starting with 1977 in the building of the former Vlasca Prefecture (built at the end of the 180o). This museum has five sections: archaeology (displaying artifacts from all epochs), ethnography, history, memorial history, and restauration-preservation. The exhibition in the history section was reorganised in 1977 , on celebrating one hundred years from the Independence, presenting significant moments of the 1877-1878 war.

In addition, in the museum, there are displayed proofs of the appearance of Giurgiu, of the fight of Michael the Great against the Ottoman Empire, of historical monuments (abbeys, churches, laic buildings), of the locals' contribution to the events of the 1848 Revolution, of the Independence War (18771878), and of the Romanians' participation at World War I (1916-1918) (Muzeul Județean „Teohari Antonescu" Giurgiu, 2021). We see that this is the only new symbol introduced in comparison with the first collage, creating a narrative based on history, on the Danube and on present achievements (i.e. the modern socialist living in blocks of flats pictured in the city centre).

Olteniţa is represented through images with political, historical, and economic significance. The contemporary socialist society is referred to using three images out of the total four of the collage (Fig. 23).

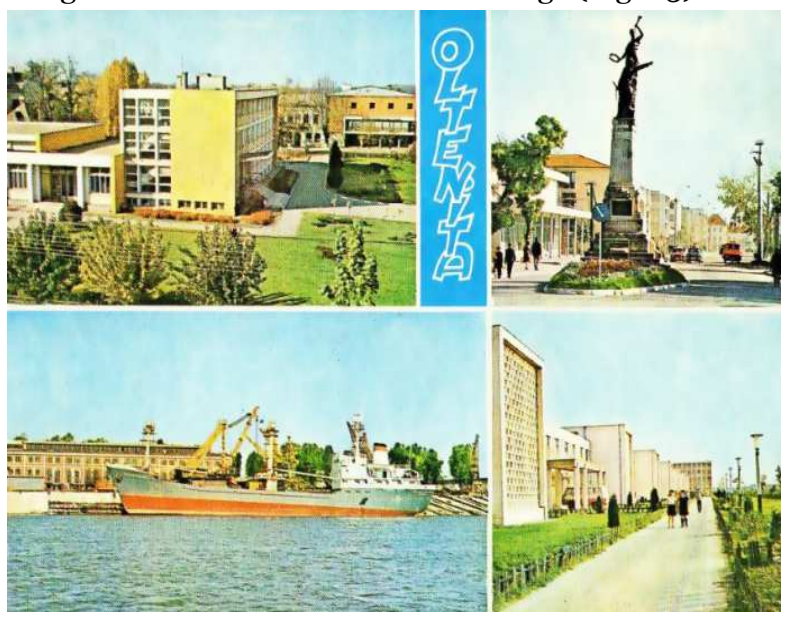

Fig. 23. Olteniţa: Inscribing state power and claims to truth and knowledge about national identity. The Popular Council, the Monument of the Heroes from World War I, the Shipyard, the Mill for Cotton and Synthetical Fibres Olteniţa (publ. in 1974, OSETCM).

The settlement is the second city by number of inhabitants and importance in Călărași County (after Călărași city) and it is a harbour at the Danube. Oltenița is created on the $23^{\text {rd }}$ of April 1853. The basic function of the town is that of harbour, complemented, in time, by the industrial one (Ghinea, 2002, p. 914). Oltenița shipyard was set up in 1940 (Fig. 23) (constructions and repair works for ships for freight and passengers, foundry, furniture factory, prefabricated elements for constructions, food, and light industry, etc.) (Ghinea, 2002, p. 914). The first image represents political power. The second one is that of a memorial: the Monument of the Heroes of Olteniţa in World War I 1916-1919, the great war for the union of all Romanians; authorship belonging to sculptor I. Iordănescu and architect I. Cernescu (radiotvoltenita.ro, n.d.). It was erected in 1930, becoming emblematic for the city.

The Mill for Cotton and Synthetical Fibres Olteniţa is presented in the last image (Fig. 23). Part of the five-year plan of $1966-1970$, for reaching the established production level of textile industry, authorities decided the building of a new spinning mill. In 1967, the Prime Minister I. Gh. Maurer signs the act for setting up Filatura Olteniţa [The Cotton Mill Olteniţa], under the guidance and control of the General Direction of the Cotton Industry. The activity object is that of producing cotton and synthetical fibres. It starts production in 1968 and from 1973 it bears the name "Filatura de Bumbac Olteniţa" [The Cotton Mill Olteniţa] (Arhivele Naţionale ale României, n.d.). 
An evocation of the mood is attached to images picturing people relaxing, talking with their friends in restaurants and terraces, enjoying free time and the cityscape or the landscape of the Danube (cf. Fig. 24 and Fig. 29). Thus, feelings are attached to these images. One can relate to the feel of the image also in the case of the two girls walking in the street in their school uniforms (Fig. 26). A sense of purpose is transmitted to the viewer.

Representations of the most necessary social services (for education, communication, and healthcare) were characteristic of rather small towns. Călărași was declared a municipium in 1968. It hosted a thermal power plant and iron and steel factories (Ghinea, 2002, p. 375). Where people appear, the city is represented as a place experienced and consumed by those inhabiting it. The socialist model of leisure is presented as a daily or urban practice (Fig. 24).

The word 'agricultural' has been in all names of the represented high school (Fig. 24) starting with 1948 when the Technical School of Agricultural Mechanics was set up in the town. In 1966, its name changes into the Agro-industrial High School Calăraşi (Mâţ, 2020).

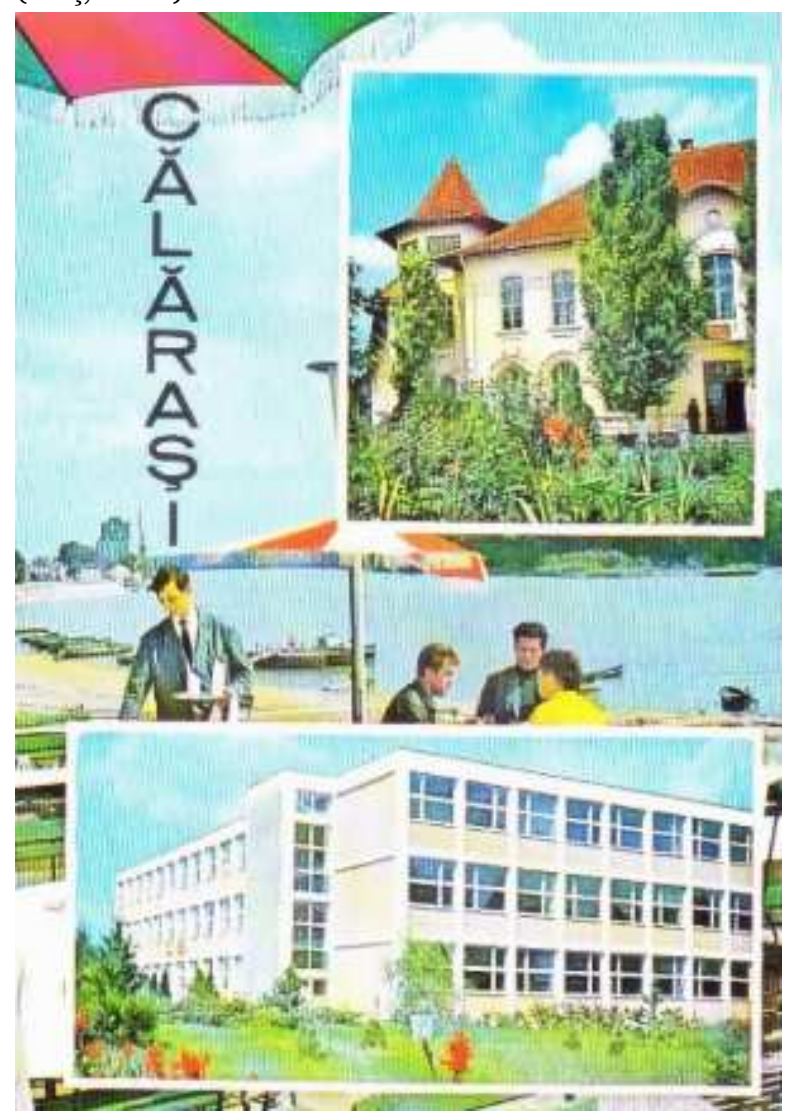

Fig. 24. Călăraşi, the city as a site of leisure, education, and communication: "Terrace-restaurant Pescăruş" [Seagull] (with the Danube in the background), Agro-industrial High School Calăraşi, Postal office (1970s, OSETCM).

Between 1836 and 1883, Brăila was porto franco (Ghinea, 2002, p. 207). Water transport was essential for Brăila, as this was one of the oldest means for transporting freight and persons along the Danube. After World War I, in Brăila, at the Agricultural Stock Exchange, the price of cereals in Europe was established. The significant spatial relation to the Danube is obvious due to systematization works at the beginning of the 19th century. In 1829, the Russian authorities of occupation decided to redraw the urbanistic plan, and this placed the new streets in the form of a crescent, where each street started from the Danube and stopped at it. For the River Station, Romanian style construction, the works were led by architect V. Hălăceanu and it was opened on the 8th of February 1909 (Munteanu, 2013, pp. 46-47).

The changes that appeared in the national economy after the 1950 s led to a radical transformation of the freight structure processed by Brăila harbour. Established as a cereal harbour for a century, it shifts to raw materials for industry and processed products of the Romanian industry. The activity of the harbour increases quantitively and qualitatively (Munteanu, 2013, p. 207).

The riverbank is an axis with two functions: economic and for leisure (including its landscape function), using old or new structures (Fig. 25). New social-spatial patterns are created redefining the territorial identity of these cities (Fig. 25, the right bottom corner). The tram (like Dacia car in other representations, cf. Ilovan, 2020d, p. 9) (Fig. 25, lower right corner, Fig. 27, lower left corner) in the image transfers its signifier as progress, modernity, to the urban landscape where it is pictured, or to the objects or buildings in front of which it is photographed. In 1901, tram city transport was introduced in Brăila. High-rise buildings underline the importance and centrality of the respective places (Fig. 25).

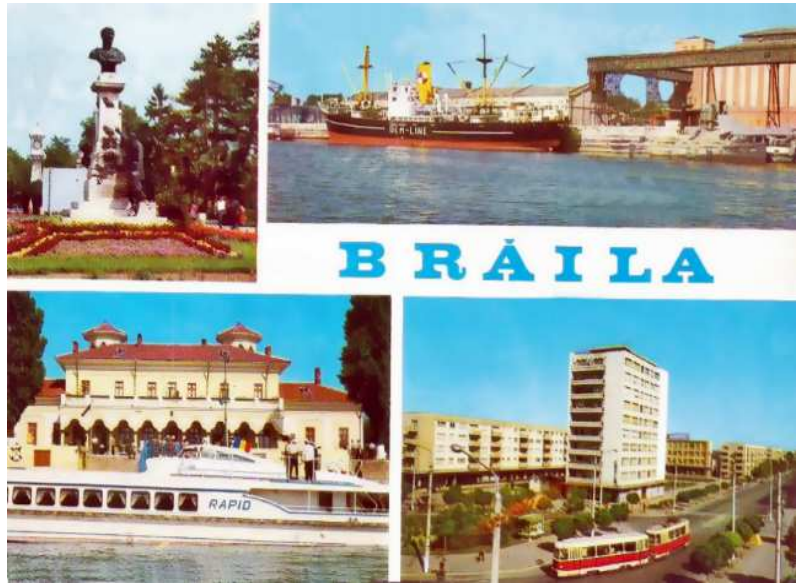

Fig. 25. Brăila, tradition and progress: Statue of Trajan, Shipyard, River Station, Hotel "Trajan" (circulated in 1978, Meridiane Publishing House).

The Monument of Trajan was inaugurated in 1906, eighteen centuries after the Romans conquered Dacia. The memorial monument is a work of art belonging to sculptor Take D. Pavelescu and architect Ioan D. Trajanescu (Fig. 25). The idea of raising this 
monument was enabled by the visit of a group of Italian students in 1902. Thus, the statue was seen also as a symbol of friendship between the Romanian and Italian people (Dominus, 2011). On the plinth of the monument, there are encrusted three bas-reliefs made of bronze, representing the she-wolf feeding Romulus and Remus, a scene from the Dacian-Roman wars, and a miniature of the Trajan's Column. At the basis of the monument, there is an old man that shows to a child the way to the Emperor. Through the inscription "Lui Marcu Ulpiu Traian, românii recunoscători” [To Marcu Ulpiu Traian, from the grateful Romanians], it is invoked the Latin origin as a factor maintaining the ethnic and cultural continuity of the Romanians. This group of statues, with a stone and marble plinth, reminds the viewer of the Dacian and Roman genesis of the Romanians and it is an emblem of Brăila (Dominus, 2011).

From the second half of the 19th century, the building of the shipyard started for major repair works (shipyard since 1864 and docks since 1883) (Fig. 25) (Ghinea, 2002, p. 207).

Until the Romanian revolution of 1989 , the focus was on the forced industrialisation of the city's economy, within the Romanian one. Besides the extant factories, authorities opened the Chemical Factories and the Celluloses and Paper Factories in Chişcani (they function starting with 1958), and the Thermal Power Plant. The Electric and Thermal Power Plant (1,950 MW), from Chişcani, starts functioning in 1973 (Fig. 26) (Ghinea, 2002, p. 206).

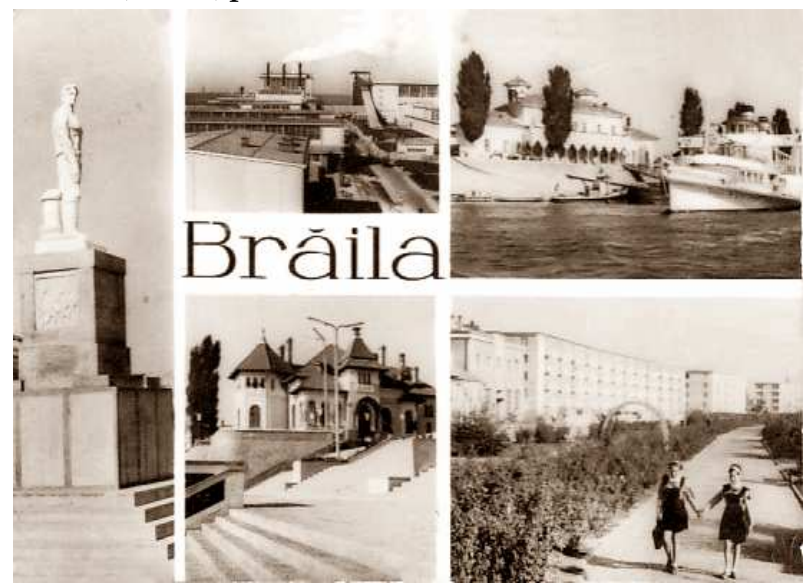

Fig. 26. The young working city of Brăila: Monument "Docherul" [The Dockworker], Electric and thermal power plant in Chişcani, River Station, House of the Agronomist, on the riverfront, nearby the political-administrative centre, School girls on boulevard Karl Marx (publ. in 1970, Meridiane Publishing House).

Besides industry, in the second collage for Brăila, appear references to its Danubian identity (Fig. 26). The Monument "Docherul" [the Dockworker], realised in 1956 by the sculptor Mircea Ştefănescu is made of a marble statue representing a worker, placed on a travertine plinth. The worker's face is vigorous, dynamic, his sight is unshaken, transmitting to the viewer the attributes of his social class. The statue also evokes a Bolshevik hero (who fought against the Romanian Army and was trialled for high treason) (Ciubotaru, 2018). This statue is now in Galaţi. Some of these monuments could be placed on the list of communism tourism and industrial heritage tourism (Ciubotaru, 2018).
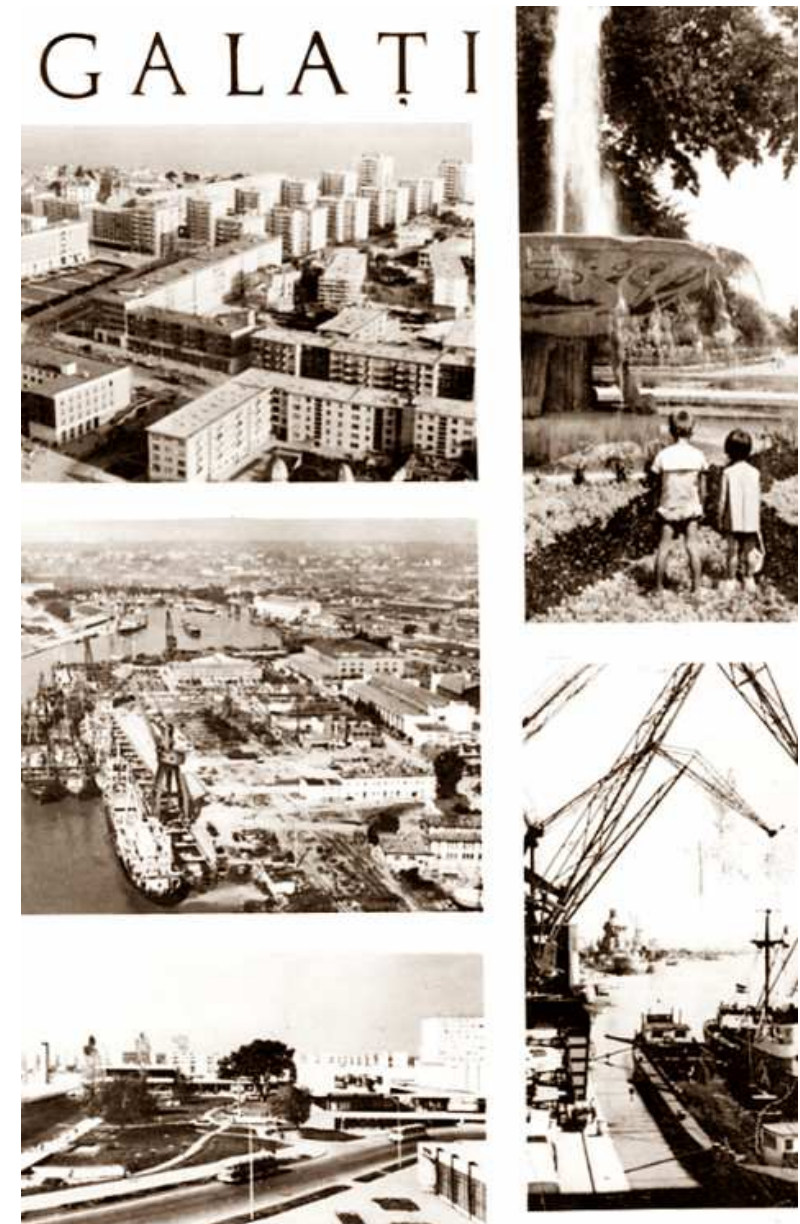

Fig. 27. Socialist city-planning in the prosperous and

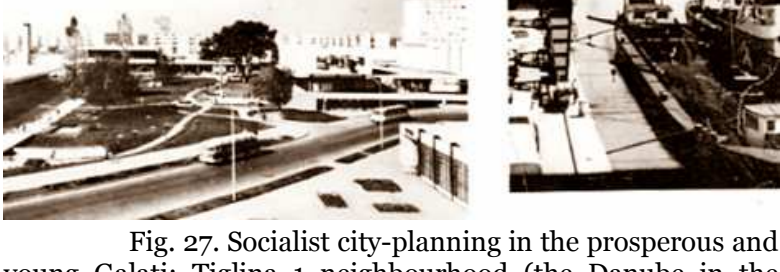
young Galați: Tiglina 1 neighbourhood (the Danube in the background), Brăilei Street in Ţiglina neighbourhood - new blocks of flats, Shipyard, A tram in the city, View of the park, Docks (publ. in the 1960s, Meridiane Publishing House).

The city of Galați has a rich history due to its position on the Danube and to the existence of the Danube-Main-Rin Canal, the most important European commercial route on a major river. This city is an important harbour, attested as such in the $15^{\text {th }}$ century; this harbour had a defining role in developing fishing, and it was an important commercial centre on the Danube. The life of the human communities was influenced directly by the Danube. In 1484 , this town is the only harbour of Moldova. Starting with the 18th century, Galaţi becomes the largest market on the inferior sector of the Danube and the most important harbour for the export of wood, cereals, honey, etc., fact confirmed by Dimitrie Cantemir in his Descriptio Moldaviae, where he reminded the fact that it was "the most famous borough of the entire Danube" (Ghinea, 2002, pp. 585-586). Due to its transformation into 
porto-franco in $1836-1883$, the town registered higher commercial and economic development, becoming, in 1841, the second town of Moldova (as importance) after Iaşi (Ghinea, 2002, p. 586). Economy developed based on the shipyard, the harbour, the iron and steel factories, and the ore harbour.

In 1944, the city of Galați is bombed by the American and German aviation in their retreat and most of the buildings, dwellings and parks are destroyed (Ghinea, 2002, p. 586). In 1945, the authorities begin the reconstruction of the city according to the communist model. In the first image of the collage, it is pictured the residential neighbourhood Tiglina 1 (Fig. 27), representation of the residential utopia, the socialist solution meant to solve a crisis of housing in the growing and industrialised urban areas.

Such representations of success were meant to justify further massive interventions in the urban landscape. Tiglina 1 is one of the first neighbourhoods of blocks of flats built in the 1960s. It lied on a loess stratum on the second terrace of the Danube. The allocation of an apartment was "a crucial part of the communist-era reward system" (cf. Borén and Gentile, 2020, p. 94) and a means of legitimising the system. Large, open spaces, which lost the social function are presented (i.e. the disappearance of narrow traditional city streets). The large and long streets were no longer meeting places, pedestrian, and habitable ones, but only channelling people to their destinations. Mass-housing represented the socialist vision of urban functionalism, including dwelling, transportation, and recreation. In this collage, we see images of socialist planning, architecture, and infrastructure facilities (Fig. 27).

In the same collage (Fig. 27), it is represented city transport with trams. In 1902, the network of electrical trams had $13 \mathrm{~km}$. Before introducing the tram, in Galați, they used carriages, buses and tramcars (pulled by horses), after the model of those in Bucharest. In 1927, the electrical tram network was 15.5 $\mathrm{km}$ long, spread over eight streets and serviced by 23 waggons. In 1956, the communist authorities contacted a Swiss firm to install a tram of high speed on the river front (Bădiţă, 2013).

The social mission of transforming the city, to match the planning ideologies and the redistributive polices of the new egalitarian system, was embodied in representations of urban development. The paternalist housing policy was reflected in the renewal of the Romanian city and in an attempt to create affective communities within the new neighbourhoods, made of people who were grateful to the regime for an increased quality of living and a sense of home. Modern socialist living was a promise that translated into reality through the blocks of individual apartments. The images with new blocks of flats and neighbourhoods in Galaţi (Fig. 27 and 28) showcase the Romanian aspirations to socialist modernity.
The representations of the urban housing project were those of prosperity, economic and political power, and, above all, of equality due to the socialist vision about development in a fair society, based on merit and satisfaction of needs for all. Housing was a key piece in the creation of the socialist way of life. In the 1970 s and 1980s, mass-housing districts produced of prefabricated materials and based on standardized designs were a major marker of the socialist nature of space in the urban area (cf. Young and Drummond, 2020, p. 304). Panel housing was a trademark in Romania, as in other socialist countries of the Eastern Europe, bringing uniformity in architectural style (Ilovan, 2020d). This was the blueprint of the new apartment neighbourhood recognisable in socialist towns and cities during that period and after. These modernization works were presented as heroic deeds in the golden age of the Romanian worker (cf. Ilovan, 2020d, 2021a, 2021b, 2021c).

The second collage represents Galaţi as a Danubian city, with a modern and prosperous urban lifestyle and a cultural emblem (Fig. 28).

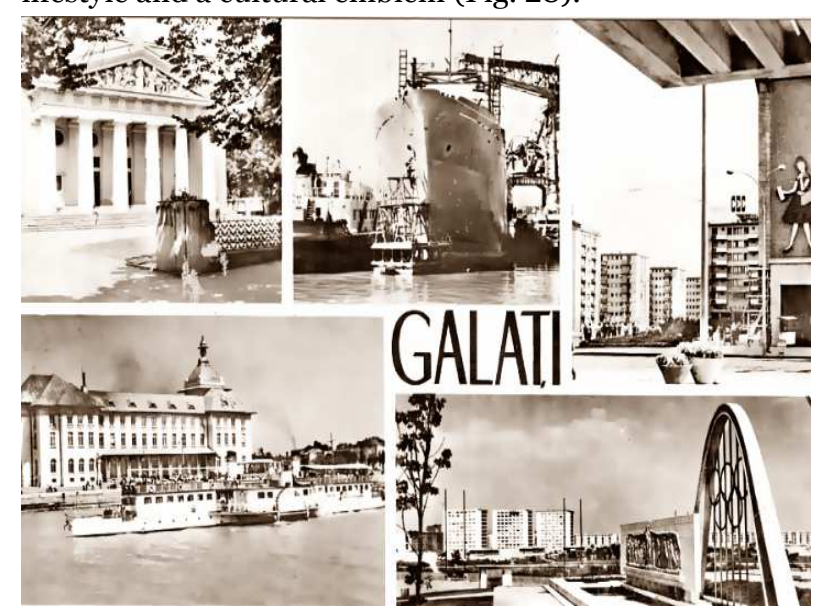

Fig. 28. Aspect of socialist urbanism, the blueprint for the Romanian communist future. Galaţi: Dramatic Theatre, Shipyard, Mazepa area - blocks of flats and the CEC building (Casa de Economii și Consemnațiuni [House for Economies and Agreements]), state-owned banking institution of Romania, set up in 1864) -, Navigation Palace with the River Station view from the harbour, Sports Hall with Olympic circles pattern (the 1960s, Meridiane Publishing House).

The first image in the collage is that of a theatre (Fig. 28). The works at the theatre building started in 1924 and were finished in 1941. With 1955, the State Theatre Galaţi started its functioning. From 1973 on, it bears the name Dramatic Theatre Galaţi (Fani Tardini, Teatrul Dramatic Galaţi, n.d.). The second image is that of the shipyard. Created in 1883 as G. Fernic et Comp, the small foundry and repair works shop extended in 1897 by including a shipyard. Until World War II and during this, the shipyard was the most important Romanian one, followed by the ones in Constanța, Drobeta Turnu Severin, and Brăila (Damen Shipyards Group, 2021). Here they built river and sea ships. The Navigation Palace (The River Station) is 
realised in 1912 according to the plans of architect Petre Antonescu (Ghinea, 2002, p. 587).

People were represented enjoying spatial comfort in the city. Faleza Dunării [Danube Riverfront] (Fig. 29) is one of the representative areas of Galați, a classical walking route. Representations of leisure practices are frequent besides the key elements of socialist progress which are the buildings: for housing, for economic activities, for consumption, for culture, etc. In Fig. 29, we can see spaces for entertainment, rest and relaxation as leisure activities which can be performed by urban inhabitants and which contribute to constructing the idea of the model citizen within state-driven leisure organization.

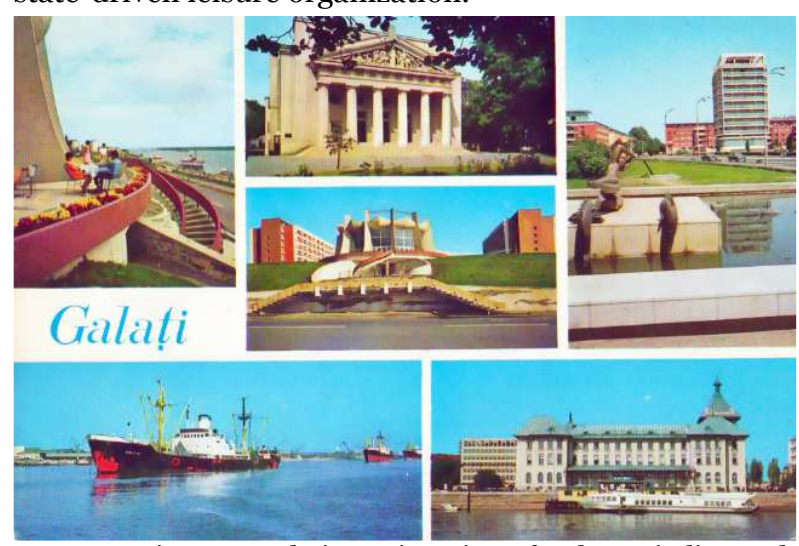

Fig. 29. Galaţi, testimonies of urban vitality and development: Riverfront, Dramatic Theatre, Restaurant "Pescarul" [The Fisherman], Hotel "Galați", Ships on the Danube, Navigation Palace-River Station (publ. in 1975, Meridiane Publishing House).

The collage also testifies that Galați was the second important harbour of Romania (after Constanţa), with a connection to the Black Sea, as the Danube is maritime from this city. Then, Restaurant "Pescarul" [The Fisherman], built in 1968 on the riverfront, in Mazepa area, placed centrally in the collage, underlines Danube-related leisure activities. The view towards the riverfront is varied as it is built on two levels and in an architectural succession of fishing boats, creating the perfect lotus (Soroceanu, 2020). This narrative is completed by Hotel "Galaţi" and the Danube. In other postcards, appears also the Universal Store "Modern" which was, in 1970 s and 1980 s, among the main commercial areas of Galați. These commercial, architectural, and cultural achievements place Galați into the representation pattern of Romanian socialist cities (Ilovan, 2020d). Representations of this city showcase iconic images of achieving socialist territorial development goals.

\section{5. "Misreading" official visuality and interacting with representations}

In researching official visual imagery and discourses, an important idea to consider is that both images and viewers are not passive, they have their own agency, they can change or resist preferred meanings. Different audiences will read images differently (Rose, 2014, p. 33). Viewers' experiences and kinds of knowledge are brought together in the moment of viewing and alter the individual's way of seeing. Thus, the meanings of the visual image are renegotiated depending on the circumstances of watching. Rose underlines that the social is "perhaps the most important modality for understanding the audiencing of images" (2014, p. 31). What is the position of the viewer in relation to these images? What is expected from the viewer when looking at these images? Places influence the viewing of images, and social processes shape the way people produce and interpret semiotic resources (Rose, 2014, p. 139).

Meanings of picture postcard collages were sometimes changed in use. An instance of such change is the text on the verso of the collages, written by senders, showing how these images and their narrative were used and transformed by their first audience (then further changed, possibly by the addressees). For a start on audiencing picture postcards, the senders' texts on the verso, which refer to the images on the front, could be used. With comments on the back of picture postcards, images are experienced differently by viewers, from the intended message of advertising an achievement or tourist promotion.

Here, we exemplify this situation with a picture postcard of Cernavodă, one among the many where the sender interacted with the images (We did not insert the picture postcard for privacy reasons). In the south-east of Cernavodă, river harbour, there is the watergate for entering and exiting the Danube-Black Sea Canal.

On the back of this postcard representing Cernavodă, there are arrows showing explanations to the images on the front side (the collage is made of three images). An arrow from the upper right image with the bridge (part of the complex of railway bridges built between 1890 and 1895 by engineer Anghel Saligny) goes on the verso where the sender says that there he unfolds his activity of "guiding and whacking the military young man!"; then, from the photo on the left, representing again the bridge, the sender writes "I think that I will end up like this if I stay much longer here"; finally, the third image represents the Headquarters of the Popular Council and from this an arrow goes to the back of the picture postcard and the sender writes ironically that that was "the meeting place of the high society in Cernavodă”.

The sender signs assuming the identity of "the canal worker", using a postscript to mention: "This is my brutification state!” The postcard was not stamped; if sent it most probably was sent in an envelope that could hide its contents. However, a question remains open: What is the effect of this image on the viewer, as addressee, when received? 
Oana-Ramona ILOVAN, Florentina-Cristina MERCIU

Journal of Settlements and Spatial Planning, Special Issue, no. 7 (2021) 15-50

Territorial Identities and Heritage. Discourses and Practices

\subsection{Discussing visual intertextuality and the discourse in school textbooks and picture postcards}

School textbooks and picture postcards were powerful knowledge-based discoursive practices which used photographs "in a specific regime of truth, so that photographs were seen as evidence of 'what was really there" (Rose, 2014, p. 193). We considered textbooks and picture postcards collages as exhibitions on the theme of economic progress, producing visual intertextuality. Collages share representations characteristic to the evolution of the Romanian society across centuries. Progress is represented as naturally continued by communists as they were the continuators of other historical personalities' work.

These images bring a renewed symbolisation of territorial representation; space is appropriated first physically and symbolically by those in power. The spatial symbolism of the Danubian settlements is just a case study about the entanglements between political power and education aiming to influence the Romanians' visuality of their country. The common or popular belief that photographs picture the real is exploited by the visual discourse in school textbooks and picture postcards.

The geographical and historical context is highly significant for understanding the meanings of representations, so the context is to be understood and analysed too, by looking for answers to a series of questions as underlined by Rose (2014, p. 15, quoting Mitchell, 1994, p. 420): "who or what represents what to whom with what and where and why?" This social context mediates the impact of the seeing of an image. Postcards and textbook images can be considered as cultural representations precisely because the ways of producing and seeing them are culturally informed (or mediated). Like images, which are location specific cultural products, ways of seeing are context specific. This explains how the viewer's seeing is prescribed through certain social practices and reading practices: when the same image is part of a school textbook or is displayed in a picture postcard.

In addition, the meanings from school textbooks could be easily transferred to images in picture postcards and enable the construction of certain correct meanings, due to the intertextuality that can be identified also for visual texts during that period. Moreover, visual discourses may produce habitual and historical ways of seeing, due to the repetition and transmission of representations over generations. Picture postcards and textbooks are the official conveyors of the "legitimate" specific territorial identities of Romania. They are memory-based and build memories for generations of Romanians. Representations of the cultural landscape during socialism contribute to the national narrative of Romania during that period and the present day.

Urban development representations were symbolically and politically charged. The presence of political power is usually expressed through at least one image in collages. The collages themselves display the city as a text, as a palimpsest, representing the most significant (for the political regime) symbols, constructing the identity layers of the urban area. Like previous research, we noticed increasing representations of economic development, since the previous period (cf. Ilovan and Maroşi, 2018).

Picture postcards have the function of advertising. They advertise socialist construction. Same of these images became symbols of development (e.g. Iron Gates I) or of the transformative power and coercion inflicted by the political regime (i.e. the Danube-Black Sea Canal). They act like a metaphor because a certain set of values is associated to them, as well as emotions, positive or negative. The analysed collages show the relationships between inhabiting the urban area, work, consumption of urban services and recreation. The signs in these collages carry higher-level meanings: for instance, the modernized urban area stands for the successful political and economic systems. They reflect the world according to the interests of those in power who in fact created them. Ideology is knowledge visually constructed by those in power to legitimize the political regime.

Spatial symbolism is most explicit through the representation of memorials highlighting historical personalities or heroes, military victories, political and economic achievements placed into highly visible places in the city. The political regime's vision of history is translated into the events and heroes picked up for representation. Naming practices for these memorials and achievements (e.g. The Friendship Bridge) are relevant in the creation of the official discourse on territorial identities. Specific events and persons were promoted officially through using statues either created before or during socialism. Those created before were reinterpreted by displaying them in collages where new relations were constructed with other symbols.

What is the strategy used in picture postcards to make the association between past and present? First, representing them together, or side by side, in the same collage and thus becoming part of the same narrative. The spatial organization of displaying images in a picture postcard collage, how different representations are placed in relation to one another, help construct the "intended" narrative and may uncover hierarchies. These images were put together due to historical and economic considerations, although also aesthetic reasons were considered to showcase the beauty of the Romanian socialist cities. Urban space is represented as a desirable place to be or to live in. 
In collages, the images are contemplated as part of a story. Through collages, the imaginary visitor of the presented places, is invited to follow a certain route and construct a particular narrative because of this guided viewing process. Signifieds (i.e. meanings) are transferred between signs in the same image (i.e. the image itself being composed of a collection of signs) or between images of the same collage. That is why collages are richer in meaning and create stories, due to the interaction among multiple images. The final signified is constructed and communicated through a collection of signifiers put together in the same image or collage. Images are signifier-signs. In structuralist geography, their signifiers had only one meaning (signified), absolute, unchangeable, while at present, in poststructuralist geography, signifiers have more meanings, depending on the readers/observers (Banini, 2019, pp. 208-210). However, it should be noted that only by having background information about the represented places, objects, people, etc., the viewer is capable to identify and understand the respective interaction and resulting narrative.

Then, repetition of visual markers in various sources is used as a persuasive strategy of the official visual discourse in order to claim truthfulness or scientific validity and certainty of its representations. The persuasiveness of the discourse consisted in rendering representations as natural, the only possible ones for the objects, people, and places it selected. The signifiers included in the city-text (cf. DellenbaughLosse, 2020) are the following: monuments, buildings, urban planning, civil and industrial architectural interventions, and styles. These were thoroughly represented in images circulated in the media of picture postcards and school textbooks and their meaning was relative to the other signifiers in related representations. They create the Romanians' belonging and identity based on particular tropes. In addition, long-term residence influenced the feelings of placeattachment to a home of the urban residents.

The pervasiveness of visual images about two major topics - heritage and development - is characteristic to the medium of picture postcards. The visual and narrative structures of collages, as well as the represented power relations (i.e. political, economic, social), are articulated through this visuality. Because this imagery was the official one (i.e. approved and produced by the state), it also claimed societal relevance concerning the way objects, topics and people were categorized.

These particular ways of seeing are intimately related to the ideological aims of the political regime and uncover the power structures embedded in the Romanian society. Images were intended to enchant the viewer with visions of socialist modernity, respectful for the past and careful about present and future and also to justify the politics of sacrifice.
Thus, picture postcards are also memorialization products, an official sanctioning of the preferred meaning attributed to places. Certain territorial identities are legitimized and other are delegitimized by lack of or scarce representation of their symbols.

According to these representations or stories in images, the new society was both materially prosperous and spiritually refined. The city is gratifying access to leisure activities promoting a set of values that help to construct the individual's identity. From the state's perspective, representations of leisure and culture, besides economic prosperity, contributed to the creation of the ideal city. These representations articulate also discourses about culture and art, and about how these should be experienced in the socialist society. Therefore, monuments in public spaces, houses of culture and theatres are foregrounded for three reasons: to display heritage, to evoke the past, and to show that culture is alive and supported by the state (represented as a key element of urban life). We could identify, in the case of these representations, that they are partly embedded in a path-dependency of discussing national identity, which reaches back to the interwar period and even to the beginning of the $20^{\text {th }}$ century, when Greater Romania was created (in 1918), or to events in the $19^{\text {th }}$ century (the 1848 Revolution and the Independence War).

These collages show that the political, economic, and cultural processes were reinforcing each other, their messages intersected and gained hegemonic status within Romanians' spatial representations of development and the urban planning elite. These are architectural signs of institutions leading political, cultural, and economic activities. They contributed to Romanians' making sense of what matters in economic development and historical memorialization. These can be perceived (if only part of them) as authentic socialist structures due to their attached symbols during that period.

These collages are a selection of images considering spatial transformation on a long-term. Which aspects of the represented city-text are the most significant for the regime (and should have been for Romanians) in the selected picture postcards? Historical memory is one significant trope. Organisation of space in the socialist city is another one. Some are overt symbols, other are more subtle. These collages display public places and landscapes, art and development, economic activities, and consumption, all are advertised.

The viewer is placed outside the represented landscape. The landmarks in the images are offered for consumption, and, at the same time, they guide the viewer, offering him or her a clear message. These are representations of the heyday of socialist urban development: landmark buildings, collective housing neighbourhoods, industrial sites, constructing a new 
Oana-Ramona ILOVAN, Florentina-Cristina MERCIU

Journal of Settlements and Spatial Planning, Special Issue, no. 7 (2021) 15-50

Territorial Identities and Heritage. Discourses and Practices

visual culture and architecture. Even if not all constructions were realised during socialism, they were integrated into the new story of socialist success and territorial development. They were all material proofs of the improved living standard. Still, these representations in picture postcards reflect many temporalities, besides the socialist one. However, all the previous ones are reinterpreted within the socialist narrative, which is the reference period of the photographs. The Danube and related activities are a central component of these cities' territorial identities.

The main represented themes are the beautiful and resourceful Danube; Danube as a bridge among countries, not a border; the glorious ancient, recent, and communist past; the prosperous present, with the following subtopics: territorial development (constructions and industry), culture and leisure. Thus, one of the represented themes is the improved standard of living (due to the equal distribution of wealth in the Romanian socialist society).

Most of the images in textbooks on Danube and the Danubian settlements are repeated in picture postcards. Because "images work by producing effects every time they are looked at" (Rose, 2014, p. 13), it is logical to assume that a repetition of the same topics and even iconic images will have a pedagogical effect on the Romanian viewer.

As authors, the way we saw these images is written in our interpretation of them. Therefore, it is relevant for our research to reflect on our academic reading of the visual imagery and the researchers' subjectivity such qualitative analysis involves. Nevertheless, we argue that the Romanian viewers during the socialist period could have made the same connections we did during our analysis and interpretation of these images. This is supported by us as we did the same or similar readings and had access to the same or similar texts that the respective audience had during that period. So, several decades later, we accessed the same visual imagery to identify the meanings that the respective viewers could have shared. However, an audience study should be realised to assess the impact of the visual discourse.

The figures we included in this article have also the function to convince the readers, in an active way, that our analysis of them is correct. Therefore, any academic discourse based on texts and their interpretation is an ideological one. It makes the readers believe that these images are not mere illustrations of what the article is telling them, but visual arguments themselves. These figures strengthen our argumentation, and, in addition, they give the readers the possibility to attach other layers of interpretation themselves.

The school and the audience (students, Romanians in general) are, besides us, co-authors of the discourse analysis, likewise the readers of this article.
However, one should also consider that visual images have their own agency, and this exceeds the researcher's interpretative effort and ability (cf. W.J.T. Mitchell, 1996; Rose, 2014, p. 223).

\section{CONCLUSIONS}

In this article, we explored the official visual discourse practice about territorial development and identities of the Romanian Danubian settlements in visual imagery during the socialist period. The two media and sources used were images in Geography of Romania textbooks and picture postcards produced and circulated during socialist Romania (1948-1989). We could identify historical heritage and territorial development as the main referent systems proposed by the regime for the metacode or dominant code (Hall, 1980, cited in Rose, 2014, p. 362) used in visual representations, as a reflection of the political ideology pervading the respective period. We concluded that the built environment is hosting stories about territorial identities. Both past and future are envisioned and interpreted based on the contemporary visual discourse ascribing meanings to the present. These representations create stories about nation and the national territory.

In socialist Romania, in the process of socialist development, a new urban spatial symbolism is created and established, needing to be represented and to become iconic. We argue that the legibility of development relies both on the material landscape and on the related visual or textual representations from that period. These materials attempted at shaping a set of values and the identities of the readers/viewers. They reflect certain choices about legitimate history, memory about the past, and territorial identity markers. The consequences of the new territorial and national narratives are significant on Romanians' construction of their self-image and their belonging to places and to local, regional, and national communities. Exploring the socialist era Romanian identity construction of the Danubian settlements, we see that the landscape is a critical touchstone for group belonging and identities of the represented places.

Their visual representations are foregrounding the cultural narrative of the respective period. Such representations are codes needed to correctly interpret the socialist realities. The socialist cultural urban landscape is a representation of power and historical relationships, it is a palimpsest of signs. Here, the visual national narrative was constructed through urban systematization, architectural and artistic interventions. In this article, we underline the creation of symbolic places referring to the past and present and the status of the Danube in this narrative.

As one of the open political goals of the regime was the creation of a set of values for educating the New 
Man: love and devotement to the homeland, to the Romanian people, and to the Romanian Communist Party (Copilaş, 2015), we argue that visual representations are testifying this pedagogical endeavour. Therefore, we underline that Romanians inherit not only the built environment, but also the representations constructed during socialism. Representations have the attribute to freeze a certain slice of time and therefore they enable us to decode "the complex relationship between the evolution of a political and economic framework and urban spatial transformation" (Young and Drummond, 2020, p. 307). Ideologies and ideological past influence present regional development.

The political regime legitimized its power through a visuality favouring economic achievements and through remembrances of the past, in two ways, or based on two resources with repeated occurrences in representations. Two main narratives appeared in these representations - about the past and about the present - because urban development was represented from two perspectives: a historical one and a territorial one. These were pervasive in the visual discourse and appeared routinely. Our aim was not to confirm these through images used in illustrations, but to interpret the narratives created by adjoining such elements (development and historical heritage) and thus reveal their ideological status. The collages negotiated and established the significance of past to the present socialist society. Their messages promote values with socialist characteristics.

Travelling through Romania, in person or mediated by visual materials, was encouraged as a visual practice enabling knowledge acquisition according to a hegemonic visuality. Which are the highlights of this visual discourse on the Danubian settlements, and which are the common tropes? Most of these representations of development are displays of the city. The audience was taught to appreciate the Romanian landscape through the lens of development and heritage in the city area. The city is pictured through instances of its becoming process. An ongoing process of change and modernizing enabled Romanians to experience modernity as dynamic spatial transformation. The key themes are city as habitation, city as leisure, city as culture, city as work.

Socialist planning casts long shadows into the post-socialist present. Due to these representations, decades later, certain spaces are identified as socialist. These socialist identifications are based on the ideological aims and policy imperatives that led to their creation: for instance, mass-housing (due to their production features and design).

Such representations might influence decisions about redevelopment and historic preservation of the same spaces. The production of represented space led to place attachment in the case of both heritage images and economic progress ones. Romanians' lived experience of the respective places would claim for preservation, especially of landmark individual buildings, which might engender a feeling of relationship to the past and their past life and thus of security and preventing alienation.

The representations of the cultural landscape of the Romanian Danubian settlements, likewise the respective landscape, are expressions of power and political choices that cannot be overstated. The objects and themes chosen for representations are symbols which exemplified political and economic superiority for the populace of Romania. Therefore, picture postcards with representations of Danubian settlements had a pedagogical intention rather than a touristic one.

Intersections of visual discourses underlie the impact of the workings of power, further established and enforced through education in school. The socialist city was intended to be a representative space from a political, economic, and social perspective, where authorities overwrote the socialist urban fabric and then represented it through officially condoned identity markers.

The analysed visual imagery shows that the political and economic transformation of Romania was strongly connected to spatial transformation. All these changes are reflected by the explored visual representations. The images offer insights into Romanian socialist urbanism that will later become "sites of socialist urban heritage" (Drummond and Young, 2020, p. 17). The past is brought selectively to the attention of the present through various memorialization objects having a cultural function in the socialist society, showing that not only the urban area, but also its representations were formatted during socialism. The socialist urban development pattern added another identity layer to the Danubian city and its image. In addition, the images introduce the new codes, signs, and stories of socialist urban life.

Our research is a grounded example, based on empirical visual evidence of how the communist system interacted with Romanians' lives, by producing an officially condoned visual discourse and set of values. Our contribution to understanding socialist spatiality through a research of the Danubian settlements' representations shows that, due to the official discourse, Romanians' attachment to the Danube could be attachment to it as nature and as economic resource.

These representations constructed and affirmed local urban identities and also contributed to the official nation-building discourse. Visual representations were glorifying and justifying rapid changes to the urban fabric and directly participated at the socialist era Romanian identity construction. They impacted how the Romanians conceived, perceived, and lived the urban space (cf. Lefebvre, 1991) during socialism and after, but nevertheless, constructing 
territorial identities at present could take the form of various and even diverging intentions when deciding the current use of the urban area (cf. Banini, 2017).

A limitation of this study is that our interpretation suffers from a sort of 'bias', it is a subjective one. We tried to solve this limitation by making our methodology as explicit as possible and thus our way of seeing these images and of interpreting them obvious to readers, as well as the cultural significance of those images. It should be noted that we underlined the links between the content of these images and the broader cultural significance of the images in the socialist context. We discussed these images, we made several insights in their uses, but attitudes to these images and how they were lived during socialism and post socialism could and should be explored in further research.

\section{REFERENCES}

Alexandrescu R. (2013), Primele cărţi poştale ilustrate româneşti (vederi 1894-1905) [The first Romanian picture postcards (1894-1905)]. Catalogare [Cataloguing], vol. 1. Editura Coresi, Bucureşti [Book in Romanian]. ISBN: 9789730147339

Anderson B. (1991), Imagined Communities: Reflections on the Origin and Spread of Nationalism. Verso, New York. ISBN: 0-86091-546-8

Andrusz G., Harloe M., Szelenyi I. (eds.) (1996), Cities after Socialism: Urban and Regional Change and Conflict in Post-Socialist Societies. Blackwell, Oxford. ISBN: 978-1-557-86164-1

Apostolache I. (2010), Popa Şapcă din Celei, apărător al identităţii naţionale [Priest Şapcă from Celei, defender of national identity]. URL: https://ziarullumina.ro/actualitate-

religioasa/stiri/popa-sapca-din-celei-aparator-al-

identitatii-nationale-19071.html. Accessed on 10.09.2020

Apple M., Christian-Smith L. (1991), The Politics of the Textbook. Routledge, London. DOI: https://doi.org/10.4324/9781315021089

Ardeleanu V., Bărgăoanu P., Bender C., Ghibedea V., Ionescu N., Onofrei V., Popeangă V., Roșca I. Şuțu M., Teodorescu Gh., Țîrcovnicu V., Valașek I., Vulcu B. (1964), Metodică. Predarea Geografiei în școala generală de 8 ani [Methodics. Teaching Geography in the 8 Years Gymnasium]. Editura Didactică și Pedagogică, București [Book in Romanian].

Arhivele Naţionale ale României [National Archives of Romania] (n.d.), Filatura de Bumbac Olteniţa (1965-200o) [Olteniţa Cotton Mill] [online].

\section{URL:}

http://arhivelenationale.ro/site/download/arhive_jude tene/calarasi/Filatura-de-Bumbac-Oltenita_19652000.pdf. Accessed on 07.11.2020.
Bagoly-Simó P. (2013), Inheriting the Tradition: A Longitudinal Analysis of Research on Geography Textbooks. In: Bruillard E., Reints A., Rodríguez Rodríguez J., Sikorová Z. (eds.), Textbooks and Educational Media in a Digital Age. $12^{\text {th }}$ IARTEM International Conference on Textbooks and Educational Media (p. 12). IARTEM, Ostrava.

Banini T. (2017), Proposing a theoretical framework for local territorial identities: concepts, questions and pitfalls. Territorial Identity and Development, 2(2), pp. 16-23. DOI: 10.23740/TID220172

Banini T. (2019), Geografie culturali. FrancoAngeli, Milano [Book in Italian]. ISBN: 978-88-917-8021-8

Banini T., Ilovan O.-R. (2021a), Conclusions: towards a new agenda for place/territorial identity research. In: Banini T., Ilovan O.-R. (eds.), Representing Place and Territorial Identities in Europe. GeoJournal Library, vol. 127. Springer, Cham, pp. 251-265, DOI: https://doi.org/10.1007/978-3-030-66766-5_17

Banini T., Ilovan O.-R. (2021b), Introduction: dealing with territorial/place identity representations. In: Banini T., Ilovan O.-R. (eds.), Representing Place and Territorial Identities in Europe. GeoJournal Library, vol. 127. Springer, Cham, pp. 1-19. DOI: https://doi.org/10.1007/978-3-030-66766-5_1

Barthes R. (1977), Image-music-text. Edited and translated by S. Heath. Fontana, London.

Bădiţă Şt. R. (2013), Galaţiul moare şi Primăria doarme! [Galați Dies and the City Hall Sleeps]. URL: https://rsbadita.wordpress.com/2013/o2/10/galatiulmoare-si-primaria-doarme/. Accessed on 04.02.2021.

Bartram R. (2010), Geography and the interpretation of visual imagery. In: Clifford N., French S., Valentine G. (eds.), Key Methods in Geography, second edition (pp. 131-140). Sage, London. ISBN: 144624363X, 9781446243633

Both Ş. (2017), Cea mai veche carte poştală ilustrată apărută pe actualul teritoriu al României. A fost pusă în circulaţie la Timişoara, în anul 1891 [The oldest picture postcard on the present territory of Romania]. Ziarul Adevărul, versiunea online [Adevărul newspaper, online version].

URL: https://adevarul.ro/locale/timisoara/foto-exclusiv-ceamai-veche-carte-postala-ilustrata-aparuta-actualulteritoriu-romaniei-fost-pusa-circulatie-timisoara-anul1891-1_5a26egb35ab6550 cb8e33dof/index.html. Accessed on 04.02.2021.

Caramelea R. (2015), A school subject serving the nation. Geography textbooks in Romania (1864-1945). History of Education \& Children's Lit., 10(1), pp. 155-176. Ceucă M. (2015), Consideraţii privind primele cărţi poştale cu răspuns plătit [Considerations on the first postcards with paid answer]. Revista Federaţiei Filatelice Române: Filateria, 652-663, 56-59.

Ciobotaru T. (2018), Relicvele de piatră ale comunismului continuă mistificarea istoriei [Stone relics of communism continue to mystify history]. URL: 
https://romanialibera.ro/social/relicvele-de-piatra-alecomunismului-continua-mistificarea-istoriei-720209. Accessed on 04.02.2021.

Consiliul de Stat [State Council] (1968), DECRET nr. 765 din 4 septembrie 1968 privind constituirea, organizarea şi funcţionarea garzilor patriotice (Acest decret a devenit Legea nr. 39/1968), BULETINUL OFICIAL nr. 116 din 5 septembrie 1968 [Decree no. 765 of the 4th of September 1968 on the setting up, organisation and functioning of the patriotic guards]. URL: http://legislatie.just.ro/Public/DetaliiDocument Afis/46433. Accessed on 06.10.2020.

Consiliul de Stat [State Council] (1972), Decretul nr. 302/1972 privind aprobarea stemelor județelor și municipiilor. Text publicat în Buletinul Oficial nr. 127 din 16 noiembrie 1972, În vigoare de la 16 noiembrie 1972 până la 11 iulie 2000 [Decree no. 302/1972 on the approval of coats of arms for counties and municipia]. URL: https://lege5.ro/Gratuit/gyydknzs/decretul-nr302-1972-privind-aprobarea-stemelor-judetelor-simunicipiilor. Accessed on 06.10.2020.

Copilaș E. (2015), Națiunea socialistă. Politica identității în Epoca de Aur [The Socialist Nation. Identity Politics during the Golden Age]. [Book in Romanian]. Polirom, Iași. ISBN: 978-9734655755

Cosgrove D., Jackson P. (1987), New directions in cultural geography. Area, 19(2), pp. 95-101.

Crang M. (2010), Visual methods and methodology. In: DeLyser D., Herbert S., Aitken S., Crang M., McDowell L. (eds.), The SAGE Handbook of Qualitative Geography. Sage, London, pp. 208-224. ISBN: 9781412919913. DOI: https://dx.doi.org/10.4135/9780857021090.n14

Cucu A.-S. (2019), Planning Labour. Time and the Foundations of Industrial Socialism in Romania. In the series International Studies in Social History, vol. 32. Berghan Books, New York. ISBN: 978-1-78920-185-7

Czepczyński M. (2008), Cultural Landscapes of PostSocialist Cities: Representations of Powers and Needs. Ashgate, Farnham. ISBN: 9781138254275

Damen Shipyards Group (2021), O istorie ce datează din anul 1893 [A History Dating Back to 1893]. URL: https://www.damen.com/en/companies/santierulnaval-damen-galati/history. Accessed on 26.11.2020.

Dăneț O., Enache M., Olănescu E. (1984), Metodica predării geografiei la clasele V-VIII [Methodics of Teaching Geography for the $5^{\text {th }}$ to the $8^{\text {th }}$ Grade]. Editura Didactică şi Pedagogică, București. [Book in Romanian].

Diener A. C., Hagen J. (2013), From socialist to post-socialist cities: narrating the nation through urban space. Nationalities Papers, 41(4), pp. 487-514.

Dittmer J. (2010), Textual and discourse analysis. In: DeLyser D., Herbert S., Aitken S., Crang M., McDowell L. (eds.), The SAGE Handbook of Qualitative Geography. Sage, London, pp. 274-286. ISBN: 9781412919913 .

DOI:

https://dx.doi.org/10.4135/9780857021090.n17
Dominus (2011), Monumentul lui Traian [Monument of Trajan].

URL:

https://brailaveche.wordpress.com/2011/11/20/monumentu l-lui-traian/. Accessed: 04.11. 2020.

Dorobanţu M. (2020), Linia Bucureşti-Giurgiu: 150 de ani de istorie a primei căi ferate din România [Bucharest-Giurgiu line, 150 years of history of the first railway in Romania]. Analele Asociaţiei Profesionale a Geografilor din România, 10, pp. 1-22.

Drummond B. W. L., Young D. (eds.) (2020), Socialist and Post-socialist Urbanisms. Critical Reflections from a Global Perspective. University of Toronto Press, Toronto. ISBN: 978-1-4426-3253-O

Dubow J. (2009), Representation. In: Gregory, D., Johnston, R., Pratt, G., Watts, M.J., Whatmore, S. (eds.), The Dictionary of Human Geography, $5^{\text {th }}$ Edition. Wiley-Blackwell, Chichester, pp. 645-646. ISBN: 978-1-405-13288-6

Dulamă M. E., Ilovan O.-R. (2015), Development of the Geography school curriculum in Romania, from the 18th Century to 1989. Transylvanian Review, 24 (Suppl. 1), 255-284.

Dulamă M. E., Ilovan O.-R. (2017), Development of Geographical education in Romania, under the influence of the Soviet education model (1948-1962). Transylvanian Review, 25(1), pp. 3-17.

Dulamă M. E., Ilovan O.-R., Bagoly-Simó P., Magdaş I. (2019), The development of the geographical education system in Romania, under the impact of World War II and during the transition to communism. Transylvanian Review, 28(Suppl. 2), pp. 219-237.

Duşoiu E. C., Gacichevici A. M. (2015), Arhitectura industrial portuară a oraşului Giurgiu. Propuneri de regenerare [The industrial port architecture of the city of Giurgiu. Regeneration proposals]. Analele Asociaţiei Profesionale a Geografilor din România, 6, pp. 5-16.

Fani Tardini, Teatrul Dramatic Galaţi (n.d.), Scurt istoric al Teatrului Dramatic Fani Tardini, Galaţi [Short History of "Fani Tardini" Dramatic Theatre, Galaţi]. URL: http://www.fanitardini.ro/istoric-teatru/. Accessed on 10.12.2020

Ferguson S. (2006), "A murmur of small voices": on the picture postcard in academic research. Archivaria, 6o, pp. 167-183.

Ghinea D. (2002), Enciclopedia geografică a României, ediţia a treia [Geographical Encyclopedia of Romania, $3^{\text {rd }}$ edition]. Editura Enciclopedică, Bucureşti. ISBN: 973-45-0396-O

Gibert M., Peyvel E. (2020), The Reshaping of PostSocialist Hồ Chí Minh City: Leisure Practices and Social Control. In: Drummond B.W.L., Young D. (eds.), Socialist and Post-socialist Urbanisms. Critical Reflections from a Global Perspective. University of Toronto Press, Toronto, pp. 263-281. ISBN: 9781442632837

Giurcăneanu C., Muşat I., Ghica Gh. (1986), Geografia Republicii Socialiste România. Manual 
pentru clasa a VIII-a, revizuit în 1981 [Geography of the Socialist Republic of Romania. Textbook for the 8th Grade, revised in 1981]. Editura Didactică şi Pedagogică, Bucureşti. [Book in Romanian].

\section{Guvernul României [Government of Romania]} (2007a), Hotărârea nr. 511/2007 privind aprobarea stemelor municipiilor Drobeta-Turnu Severin și Orşova, județul Mehedinți, Monitorul Oficial, Partea I nr. 386 din 07 iunie 2007 [Decision no. 511/2007 about the approval of the coat of arms for Drobeta-Turnu Severin and Orşova municipia, Mehedinți County]. URL: https://lege5.ro/Gratuit/geydmmbxgq/hotararea-nr511-2007-privind-aprobarea-stemelor-municipiilordrobeta-turnu-severin-si-orsova-judetul-mehedinti.

Accessed on 20.01.2021.

Guvernul României [Government of Romania] (2007b), Stema județului Mehedinți | Hotărâre 791/1999, Anexa Nr. 3 - Descrierea şi semnificațiile elementelor însumate ale stemei județului Mehedinți [Coat of arms for Mehedinți County | Decision 791/1999, Annex No. 3 - Description and significance of the elements on the coat of arms]. URL: https://lege5.ro/Gratuit/giztamzx/descrierea-sisemnificatiile-elementelor-insumate-ale-stemeijudetului-mehedinti-hotarare-791-

1999?dp=giydsmrsgyztc. Accessed on 20.01.2021.

Hajdú Z., Paasi A. (1995), The changing image of Finland in geographical texts in Hungary: a contextual analysis. Fennia, 173, pp. 33-51.

Hall S. (1997), Introduction. In: Hall S. (ed.), Representation: Cultural Representations and Signifying Practices. Sage, London, pp. 1-12. ISBN-13: 978-0761954323, ISBN-10: 0761954325

Iancu M., Motrescu V., Florescu V. (1989), Geografia Republicii Socialiste România. Manual pentru clasa a IV-a, variante similare publicate în 1960, 1986 [Geography of the Socialist Republic of Romania. Textbook for the $4^{\text {th }}$ Grade], similar variants published in 1960, 1986. Editura Didactică şi Pedagogică, Bucureşti. [Book in Romanian]. ISBN: 9733001341

Iancu M., Motrescu V., Negulescu M. B. (1985), Geografia Republicii Socialiste România. Manual pentru clasa a IV-a [Geography of the Socialist Republic of Romania. Textbook for the $4^{\text {th }}$ Grade]. Textbook elaborated in 1960, reviewed in 1981, re-edited for the 1985-1986 school year. Editura Didactică şi Pedagogică, Bucureşti. [Book in Romanian].

Ilovan O.-R. (2019), Visual imagery and propaganda during Communist Romania (1948-1989): picture postcards as a tool. Connections. A Journal for Historians and Area Specialists (online), 18.05.2019. URL: www.connections.clio-online.net/article/id/artikel4767. Accessed on 10.12.2020.

Ilovan O.-R. (2020a), Building characters and territorial identities during socialist Romania, in comics for communist pioneers. Romanian Journal of
Population Studies, 14(2), pp. 45-84. DOI: https://doi.org/10.24193/RJPS.2020.2.03

Ilovan O.-R. (2020b), Discursul oficial despre identitatea teritorială a României în prezent [The Official Discourse about the Territorial Identity of Romania at Present]. Presa Universitară Clujeană, Cluj-Napoca. [Book in Romanian]. ISBN: 978-606-37-0923-4

Ilovan O.-R. (2020c), Making space and nation meaningful through borders and their representations in Romanian geography textbooks, during the first half of the $20^{\text {th }}$ century. Territorial Identity and Development, 5(2), forthcoming.

Ilovan O.-R. (2020d), The development discourse during socialist Romania in visual representations of the urban area. Journal of Urban History, pp. 1-35. DOI: $10.1177 / 0096144220982957$

Ilovan O.-R. (2021a), Comics for pioneers. Representations of modernisation and class identities in socialist Romania. Transylvanian Review forthcoming.

Ilovan O.-R. (2021b), Visual discourse on territorial development and political identities in socialist Romania, in comics for pioneers. Finisterra forthcoming.

Ilovan O.-R. (2021c), Visual discourse and urban spatial identity in picture postcards during socialist Romania (1948-1989). In: Banini T., Ilovan, O.-R. (eds.), Representing Place and Territorial Identities in Europe - Discourses, Images, and Practices. Springer, Cham, pp. 127-142. DOI: https://doi.org/10.1007/9783-030-66766-5_9

Ilovan O.-R., Bagoly-Simó P., Herbstritt G. (2018), Visual discourse in Romanian geography textbooks during socialism (1948-1989). Romanian Review of Geographical Education, 7(2), pp. 59-70.

Ilovan O.-R., Maroși Z. (2018), Markers of visual identity: industrial sites and landscapes in picture postcards during the socialist period of Romania. Acta Technica Napocensis: Civil Engineering \& Architecture, 61(3), 132-151.

Ilovan O.-R., Maroşi Z., Adorean E.-C., Ursu C.D., Kobulniczky B., Dulamă M. E., Colcer Al.-M. (2019), Learning and research by integrating the ICT and the theory of representations: mapping the industrial areas of Cluj-Napoca. Romanian Review of Geographical Education, 8(2), pp. 58-77. DOI: 10.24193/RRGE220194

Kristeva J. (1980), Desire in Language: A Semiotic Approach to Literature and Art. Columbia University Press, New York. ISBN: 0231048068

Kučerová S. R., Kučera Z., Novotná K. (2018), Formation of a regional image through geography textbooks: the case of north-west Bohemia. Norsk Geografisk Tidsskrift, 72(3), pp. 176-195. DOI: 10.1080/o0291951. 2018.1468811

Laakso V., Östman J. (eds.) (1999), Postikortti Diskurssina [The Postcard as Discourse]. Hämeenlinna, 
Finland: Korttien Talo. [Book in Finnish]. ISBN: 95197313269789519731322

Laakso V., Östman J. (eds.) (2001), Postikortti Sosiaalisessa Kontekstissa (The Postcard in Its Social Context). Korttien Talo. Hämeenlinna. [Book in Finnish]. ISBN: 95197313349789519731339

Lăcriţeanu S., Popescu I. (2007), Istoricul tracţiunii feroviare din România 1854-1918 [The History of Railway Traction in Romania 1854-1918], vol. 1. Editura Asab, Bucureşti. [Book in Romanian]. ISBN: 9789737725318

Lefebvre H. (1991), The Production of Space. WileyBlackwell, Oxford. ISBN: 978-0-631-18177-4

Lefter A. I. (2017), O lecţie de curaj şi mărturisire în perioada comunistă. Preotul Nicolae Dimitriu şi fiul său Ioan [A lesson of courage and acknowledgement during the communist period. The priest Nicolae Dimitriu and his son Ioan]. In: Stanciu V., Sonea C. (eds.), Mărturisirea credinței prin cuvânt şi artă în Biserica Ortodoxă Română în perioada comunismului [Acknowledging faith through word and art in the Romanian Orthodox Church during Communism]. Presa Universitară Clujeană, Cluj-Napoca, 197-210. [Book in Romanian]. ISBN: 978-606-0296-9

Liceul Teoretic Alexandru Ioan Cuza, Corabia (2019), Scurt istoric al Liceului Teoretic "Alexandru Ioan Cuza" Corabia [Short History of "Alexandru Ioan Cuza" Theoretical High School]. URL: https://www.cuzacorabia.ro/page.php?page=1.

Accessed on 29.01.2021.

Light D., Young C. (2010), Reconfiguring Socialist urban landscapes: the 'left-over' spaces of statesocialism in Bucharest. Human Geographies, 4(1), 5-16. McClelland J. (2020), Planning for "Renaissance": vanguard urbanism in Addis Ababa. In: Drummond B.W.L., Young D. (eds.), Socialist and Post-socialist Urbanisms. Critical Reflections from a Global Perspective. University of Toronto Press, Toronto, pp. 153-167. ISBN: 9781442632837

Mayhew R. J. (2015), Enlightening choices: a century of Anglophone canons of the geographical tradition. Journal of Historical Geography, 49, pp. 9-20.

Manea G. (2003), Naturalitate şi antropizare în Parcul Natural Porţile de Fier [Nature and anthropization in Iron Gates Natural Park] Editura Universităţii din Bucureşti, Bucureşti. ISBN: 973-575-802-4

Mândruț O., Ungureanu V., Mierlă I. (1982), Metodica predării geografiei la clasele IX-XII [Methodics of Teaching Geography for the 9th to the $12^{\text {th }}$ Grade]. Editura Didactică și Pedagogică, București. [Book in Romanian]. ISBN: 978-606-0296-9

Mârza R. (2015), Primul război mondial reflectat în manualele şcolare de istorie din România (până la 1989) [World War I reflected in history of Romania school textbooks (until 1989)]. In: Bolovan I., Ghitta O. (eds.), Istoria ca datorie: omagiu academicianului IoanAurel Pop [History as Duty. Homage to the
Academician Ioan-Aurel Pop for His $60^{\text {th }}$ Birthday]. Academia Română, Centrul de Studii Transilvane, 1035-1049. [Book in Romanian]. ISBN: 9737784987

Mârza R. (2018), Frânturi din istoria Clujului în Belle Époque prin cărți poștale [Pieces from the History of Cluj in Belle Époque through Postcards]. In: Lupescu Makó M. (coord.), Costea I., Ghitta O., Sipos G., Rüsz-Fogarasi E. (eds.), Cluj - Kolozsvár - Klausenburg 700. Várostörténeti Tanulmányok. Studii de Istorie Urbană. Erdélyi Müzeum Egysület, Kolozsvár, pp. 259-269. [Book in Romanian and Hungarian]. ISBN: 978-606-739-102-2

Mâţ V. (2020), Liceul Tehnologic „Sandu Aldea” din Călăraşi îşi redobândeşte numele de liceu agricol! ["Sandu Aldea” Technological High School of Călăraşi Regains Its Name of Agricultural High School]. URL: https://www.revista-ferma.ro/articole/dezvoltarerurala/liceul-tehnologic-sandu-aldea-din-calarasi-isiredobandeste-numele-de-liceu-agricol. Accessed on 21.01.2021.

Merciu F.-C., Ilovan O.-R., Cercleux, A.-L. (2020), Visual imagery and construction of territorial identity through iconic buildings. Case study: the Romanian Athenaeum, Bucharest. Territorial Identity and Development, 5(1), pp. 37-67. DOI: http://doi.org/10.23740/TID120203

Merciu F.-C., Cercleux A.-L., Merciu G.-L. (2021), Identification and interpretation of the territorial identity elements of a small industrial town using postcards. Case study: Anina, Romania. In: Banini T., Ilovan O.-R. (eds.), Representing Place and Territorial Identities in Europe - Discourses, Images, and Practices. Springer, Cham, pp. 143-158. DOI: https://doi.org/10.1007/978-3-030-66766-5_10

Mitchell W. J. T. (1996), What do pictures really want? October, 77, 71-82.

Mochnács T. R. (2015), Prima carte poştală ilustrată timişoreană [The first picture postcard published in Timişoara]. Lecturn, III, 2(10), pp. 2-4.

Morar-Vulcu C. (2007), Republica îşi făureşte oamenii: construcţia identităţilor politice in discursul oficial din România, 1948-1956 [The Republic Creates Its People. The Construction of Political Identities in the Romanian Official Discourse (1948-1956)]. Eikon, Cluj-Napoca. [Book in Romanian]. ISBN: 9789737570529

Munteanu I. (2013), Portul Brăila - Mărire şi decădere [Brăila Harbour - Rise and Fall]. Proilavia, Brăila. [Book in Romanian]. ISBN: 978-6o6-8375-35-9

Muzeul Județean „Teohari Antonescu” Giurgiu (2021), Muzeul Județean „Teohari Antonescu” Giurgiu [County Museum "Teohari Antonescu" Giurgiu]. URL: https://www.muzeulgiurgiu.ro/. Accessed on 21.01.2021. Niţă A. (2021), Rethinking Lynch's “The Image of the City" model in the context of urban fabric dynamics. Case study: Craiova, Romania. Journal of Settlements and Spatial Planning, SI 7, pp. 5-14. DOI: 10.24193/JSSPSI.2021.7.02 
Paasi A. (1999), The changing pedagogies of space: the representation of the other in Finnish school geography textbooks. In: Brunn S. D., Buttimer A., Wardenga U. (eds.), Text and Image: Social Construction of Regional Knowledges. Institut für Länderkunde, Leipzig, pp. 226-237. ISBN: 9783860820339

Păsăilă V. (2004), Presa în istoria modernă a românilor [The press in the modern history of the Romanians]. Editura Fundaţiei Pro, Bucureşti. ISBN: 973-8434-46-7

Posea G., Bogdan O., Zăvoianu I. (coord.) (2005), Câmpia Română, Dunărea, Podişul Dobrogei, Litoralul românesc al Mării Negre şi Platforma Continentală [The Romanian Plain, The Danube, The Dobrudja Tableland, The Romanian Seaside to the Black Sea and the Continental Platform], vol. V. Editura Academiei Române, Bucureşti, pp. 502-537. [Book in Romanian]. ISBN: 9732710764

radiotvoltenita.ro (n.d.), Olteniţa de altadatăMonumentul Eroilor Olteniţeni din Primul Război Mondial 1916-1919 [Olteniţa of the Past - Monument of the Heroes of Olteniţa in World War I 1916-1919]. URL: https://radiotvoltenita.ro/monumentul-eroilorolteniteni-din-primul-razboi-mondial-1916-1919/. Accessed on 22.01.2021.

Rose G. (2014), Visual Methodologies. An Introduction to Researching with Visual Materials, Third edition. Sage, London. ISBN: 1473948908

Rusnac M. (2011), Cea mai veche cale ferată din România actuală: Oraviţa-Baziaş [The Oldest Railway in Present-day Romania: Oraviţa-Baziaş] (online). URL: https://istoriabanatului.wordpress.com/2011/o9/o6/m ircea-rusnac-cea-mai-veche-cale-ferata-din-romaniaoravita-bazias/. Accessed on 09.02.2021.

de Saussure F. (1986), Course in General Linguistics. Edited by Bally C., Sechehaye A., with the collaboration of Riedlinger A. Translated and annotated by Harris R. Open Court, Chicago and La Salle.

Silivestru O. (2018), 1985 - Ceauşescu a hotărât: Televiziunea Română să funcţioneze doar două ore pe zi [1985: Ceausescu decided: Romanian Television to operate only two hours a day]. URL: https://www.rador.ro/2018/02/19/1985-ceausescu-ahotarat-televiziunea-romana-sa-functioneze-doardoua-ore-pe-zi/. Accessed on 31.03.2021.

Silova I., Yaqub M. M., Palandjian G. (2014), Pedagogies of space. (Re)Mapping national territories, borders, and identities in post-Soviet textbooks. In: Williams J.H. (ed.), (Re)Constructing Memory: School Textbooks and the Imagination. SENSE Publishers, Rotterdam, pp. 103-128. ISBN: 978-94-6209-656-1. DOI: https://doi.org/10.1007/978-94-6209-656-1_6

Soroceanu L. (2020), Atunci și acum - Galați [Then and Now - Galați]. URL: https://muzeul comunismului.ro/atunci-si-acum-galati/. Accessed on 28.01.2021.
Ştefan A. (2017), Postcard transfer across the Iron Curtain: tourism and transnational exchanges in Socialist Romania during the 1966s to 1980 s. International Journal for History, Culture and Modernity, 5(1), pp. 169-195.

The Town Hall of Corabia (2021), Corabia. Pagini de istorie [Corabia. History Pages]. URL: https://www.primariacorabia.ro/ORASUL\%20CORABI A/istoric.html. Accessed on 10.01.2021.

Tufescu V., Giurcăneanu C., Mierlă I. (1981), Geografia Republicii Socialiste România. Manual pentru clasa a XII-a [Geography of the Socialist Republic of Romania. Textbook for the $12^{\text {th }}$ Grade]. Editura Didactică şi Pedagogică, Bucureşti. [Book in Romanian].

Venezky R. (1992), Textbooks in school and society. In: Jackson P.W. (ed.), Handbook of Research on Curriculum. Macmillan, New York, pp. 438-461. ISBN: 9780029003855

Verdery K. (1991), National Ideology Under Socialism: Identity and Cultural Politics in Ceaușescu's Romania. University of California Press, Berkeley. ISBN: 9780520072169

Vibha A. (2009), Framing the image of Sikkim. Visual Studies, 24(1), pp. 54-64.

Vijulie I., Preda M., Lequeux-Dincă A. I., Cuculici R., Matei E., Mareci A., Manea G., Tudoricu A. (2019), Danube Floodplain's restoration: economic productivity vs ecological protection. Case study: Danube's sector between Olt and Vedea. Sustainability, 11, 6211. DOI: 10.3390/su11226211

Williams J. H. (2014), Nation, state, school, textbook. In: Williams J.H. (ed.), (Re)Constructing Memory: School Textbooks and the Imagination. SENSE Publishers, Rotterdam, pp. 1-9. ISBN: 978-94-6209656-1. DOI: https://doi.org/10.1007/978-94-6209-6561_1

Winiwarter V. (2008), Nationalized nature on picture postcards: subtexts of tourism from an environmental perspective. Global Environment, 1, pp. 192-215.

Young D., Drummond L. B. W. (2020), Conclusion. In: Drummond B.W.L., Young D. (eds.), Socialist and Post-socialist Urbanisms. Critical Reflections from a Global Perspective, University of Toronto Press, Toronto, pp. 301-308. ISBN: 9781442632837

Zahariade A. M. (2011), Arhitectura în proiectul comunist. România 1944-1989/ Architecture in the Communist Project. Romania 1944-1989. Simetria, Bucureşti. [Book in Romanian and English]. ISBN: 9789731872179

Zotic V., Alexandru D.-E. (2015), Operational structures in urban and rural strategic development. Journal of Settlements and Spatial Planning, 6(2), pp. 107-120.

Zukin S. (1993), Landscapes of Power: From Detroit to Disney World. University of California Press, Berkeley. ISBN: 9780520082885 